\title{
Involvement of high-valent manganese-oxo intermediates in oxidation reactions: realisation in nature, nano and molecular systems
}

\author{
Balamurugan Mani, Saravanan Natarajan, Heonjin Ha, Yoon Ho Lee and Ki Tae Nam*
}

\begin{abstract}
Manganese plays multiple role in many biological redox reactions in which it exists in different oxidation states from $\mathrm{Mn}(\mathrm{II})$ to $\mathrm{Mn}(\mathrm{IV})$. Among them the high-valent manganese-oxo intermediate plays important role in the activity of certain enzymes and lessons from the natural system provide inspiration for new developments of artificial systems for a sustainable energy supply and various organic conversions. This review describes recent advances and key lessons learned from the nature on high-valent Mn-oxo intermediates. Also we focus on the elemental science developed from the natural system, how the novel strategies are realised in nano particles and molecular sites at heterogeneous and homogeneous reaction conditions respectively. Finally, perspectives on the utilisation of the high-valent manganese-oxo species towards other organic reactions are proposed.
\end{abstract}

Keywords: High-valent, Mn-oxo, OEC, RNR, Biomimetic

\section{Introduction}

Manganese plays an essential role in many biological processes and undergoes changes in redox state during catalysis and exists in different oxidation states from $\mathrm{Mn}(\mathrm{II})$ to $\mathrm{Mn}(\mathrm{IV})$. Among many different manganese proteins/ enzymes, we are interested in the oxygen evolving complex and ribonucleotide reductases as it involved in generating high-valent intermediates for the catalytic activity. During the past year, significant advances has been made in understanding the biological chemistry of oxygen evolving complex and ribonucleotide reductase (RNR) class Ib and Ic and the unique redox properties of highvalent manganese species involved in the catalytic cycle of these enzymes are essential in the reactivity of these enzymes (Table 1) [1-6]. The oxygen evolving complex containing $\mathrm{Mn}_{4} \mathrm{CaO}_{5}$ cluster, catalyses one of the most important biological reactions occurring in the plants such as light driven oxidation of water to oxygen and

*Correspondence: nkitae@snu.ac.kr

Department of Materials Science and Engineering, Seoul National University, Seoul 151-744, South Korea protons. Significant progress has been made in understanding the structure and function of the OEC, however, the mechanism of $\mathrm{O}-\mathrm{O}$ bond formation still remains elusive to experimentalists [7-14]. In many organisms, the manganese containing class $\mathrm{Ib}$ and Ic Ribonucleotide reductases (RNRs) are involved in catalysing the conversion of ribonucleotides to deoxyribonucleotides, which is the precursor for DNA replication and repair. RNR class I can be divided into subclasses Ia-Ic is based on differences in structure and metal cofactor. Class Ia RNR is expressed in all mammals and contains FeFe cofactor, whereas class Ib and Ic RNR has only been found in pathogenic bacteria and a dimanganese(III) cofactor in Ib and $\mathrm{Mn}-\mathrm{Fe}$ cofactor in Ic were identified (Table 1) [15-28]. In addition, mononuclear $\mathrm{Mn}(\mathrm{III})$-oxygen intermediates and $\mathrm{Mn}$ (II) ions as Lewis acid catalysts are used by various manganese enzymes of metabolic importance [4-6]. Many issues remain to be answered about the redox properties of enzyme-bound manganese center and the nature of the high-valent intermediate species involved in the catalytic mechanism. So these enzymes have served as inspiration for making model complexes 
Table 1 High-valent Mn-oxo intermediates involved in OEC and RNR

\begin{tabular}{|c|c|c|c|}
\hline Name & Biological reaction & Resting state & High valent Intermediates \\
\hline Oxygen evolving complex & $\mathrm{H}_{2} \mathrm{O}$ splitting & {$\left[\mathrm{Mn}_{4} \mathrm{CaO}_{5}(\mathrm{Glu})_{3}(\mathrm{Asp})_{2}(\mathrm{Ala})(\mathrm{His})\right]$} & $M n^{I V}-O / M n^{V}=0$ \\
\hline Ribonucleotide reductase (RNR Ib) & Tyrosine radical generation & $\begin{array}{l}{\left[\mathrm{Mn}_{2}^{\|}(\mathrm{Glu})_{3}(\mathrm{Asp})(\mathrm{His})_{2}\left(\mathrm{OH}_{2}\right)_{2}\right] \text { with } \mathrm{Nrdl}} \\
\quad \text { cofactor }\end{array}$ & Diamond core $M n^{I V}-(\mu-O)(\mu-O H)-M n^{I I I}$ \\
\hline Ribonucleotide reductase (RNR Ic) & Cysteine radical generation & {$\left[\mathrm{Mn}^{\|} \mathrm{Fe}^{\|}(\mathrm{Glu})_{4}(\mathrm{His})_{2}\right]$} & Diamond core $M n^{I V}-\left(\mu-O_{2}\right)-F^{I V}$ \\
\hline $\begin{array}{l}\text { Ribonucleotide reductase (may be } \\
\text { RNR Id) }\end{array}$ & Tyrosine radical generation & $\begin{array}{l}{\left[\mathrm{Mn}^{\|} \mathrm{Mn}{ }^{\|}(\mathrm{Asp})(\mathrm{Glu})_{3}(\mathrm{His})_{2}\right] \text { without Nrdl }} \\
\text { cofactor }\end{array}$ & Diamond core $M n^{I V}-\left(\mu-O_{2}\right)-M n^{I I I}$ \\
\hline
\end{tabular}

capable of mimicking biological functions or performing synthetically useful organic and other transformations applicable to industrial level. Recent developments in bioinspired manganese chemistry has led to highly active models of the oxygen-evolving complex (OEC), oxygen activating complexes and catalysts for efficient and selective epoxidation, $\mathrm{C}-\mathrm{H}$ bond oxidation and other organic conversions. Notably, central role of high-valent $\mathrm{Mn}$ oxygen species in reactivity of Mn-dependent enzymes and model systems were investigated towards these reactions. In this review, the key lessons about high-valent manganese-oxo intermediates involved in catalytic cycles of manganese based enzymes are discussed. Based on the fundamental science developed from the natural system, how the novel strategies are realised in molecular sites and nano particles at homogeneous and heterogeneous condition for many different oxidations reactions are presented with previously demonstrated examples.

\subsection{Structure and function of oxygen evolving complex (OEC)}

Water splitting is one of the most important biochemical reactions on earth in which the light energy is converted into biologically useful chemical energy and molecular oxygen catalysed by oxygen evolving complex in PSII. The water oxidation cycle is catalysed by OEC involves a series of five intermediate states that are known as $\mathrm{S}$ states (Kok cycle). The structural and mechanistic information of the OEC, consisting of a $\mathrm{Mn}_{4} \mathrm{CaO}_{5}$ cluster and the structure of PSII has been studied extensively by $\mathrm{X}$-ray crystallography and significant progress has been made in understanding the inorganic and physical chemistry of five different states S0-S4 [10, 29-38]. Nonetheless the identity of the substrate water molecules and the mechanism of the coupling of $\mathrm{O}-\mathrm{O}$ bond are still elusive. Because most of the collected X-ray crystal structures of PSII using conventional synchrotron radiation have suffered from radiation-induced Mn reduction [39]. Even though, in the 1.9- $\AA$ resolution PSII structure the electron densities were clearly separated for all the metal ions and bridging oxygen atoms allowing the clear cut prediction of all the atoms $[34,36]$. The oxygen-evolving complex containing an inorganic $\mathrm{Mn}_{4} \mathrm{CaO}_{5}$ cluster in which the four $\mathrm{Mn}$ ions and one $\mathrm{Ca}$ ion are connected by $\mu$-oxo bridges (Fig. 1) [7-14, 29-38]. The $\mathrm{Mn}_{4} \mathrm{CaO}_{5}$ cluster contains a distorted cuboidal $\mathrm{Mn}_{3} \mathrm{O}_{4} \mathrm{Ca}$ unit formed by three $\mathrm{Mn}$ ion and one $\mathrm{Ca}$ ion and four bridging oxo groups. The fourth $\mathrm{Mn}$ ion is located outside the cuboidal unit and linked through two oxo-bridges provided by O4 to one of its corners and $\mathrm{O} 5$ to the other corner. The $\mathrm{Mn}_{4} \mathrm{O}_{5} \mathrm{Ca}$ cluster is also surrounded and stabilised by six carboxylate ligands from two aspartate (D1-Asp170, D1-Asp342), three glutamate (D1-Glu189, D1-Glu333, CP43-Glu354) and one alanine ligands (D1-Ala344) and one nitrogen ligand from histidine (D1-His332) residues (Fig. 1b) [34, 36]. Also two water molecules are coordinated to both the terminal $\mathrm{Mn}$ ion and $\mathrm{Ca}$ ion at the active sites. The $\mathrm{Mn}_{4} \mathrm{CaO}_{5}$ cluster structure is in highly distorted configuration, which enables the cluster to easily undergo structural rearrangements during the catalytic cycle and considered as a salient feature of the cluster. The distorted configuration of the $\mathrm{Mn}_{4} \mathrm{CaO}_{5}$ cluster is originated mainly from the incorporation of calcium ion in cuboidal unit because it alters the $\mathrm{Ca}-\mathrm{O}$ and $\mathrm{Mn}-\mathrm{O}$ distances. Among the five oxygen atoms, the bond distances of $\mathrm{O} 1-\mathrm{O} 4$ to their nearby $\mathrm{Mn}$ ions in the range of 1.8-2.2 $\AA$ and the distance between $\mathrm{O} 5$ and its nearby Mn ions is in the range of 2.4-2.6 $\AA$ revealing that the $\mathrm{O} 5$ is coordinated very weekly with all the nearby $\mathrm{Mn}$ ions mainly due to the presence of $\mathrm{Ca}$ (II) ion. The incorporation of the $\mathrm{Ca}(\mathrm{II})$ ion in the metal cluster for high level distortion in the cuboidal structure and the unique coordination pattern of the $\mu$-oxo-bridged oxygen atoms and their $\mathrm{H}$-bonding interaction with either amino acid residues or water molecules are the important factors contributing to the flexibility and catalytic activity of the OEC [11, 12, 14, 34, 36, 37].

During the reaction initially light energy is absorbed by chlorophyll- $a\left(\mathrm{P}_{680}\right)$ and becomes excited and donates one electron to the initial electron acceptor pheophytin moiety, which consequently transfers the electron to the primary and secondary plastoquinone acceptors. The oxidized $\mathrm{P}_{680}{ }^{+}$is reduced by a nearby redox active tyrosine residue, which in turn oxidizes a $\mathrm{Mn}_{4} \mathrm{CaO}_{5}$ cluster for 

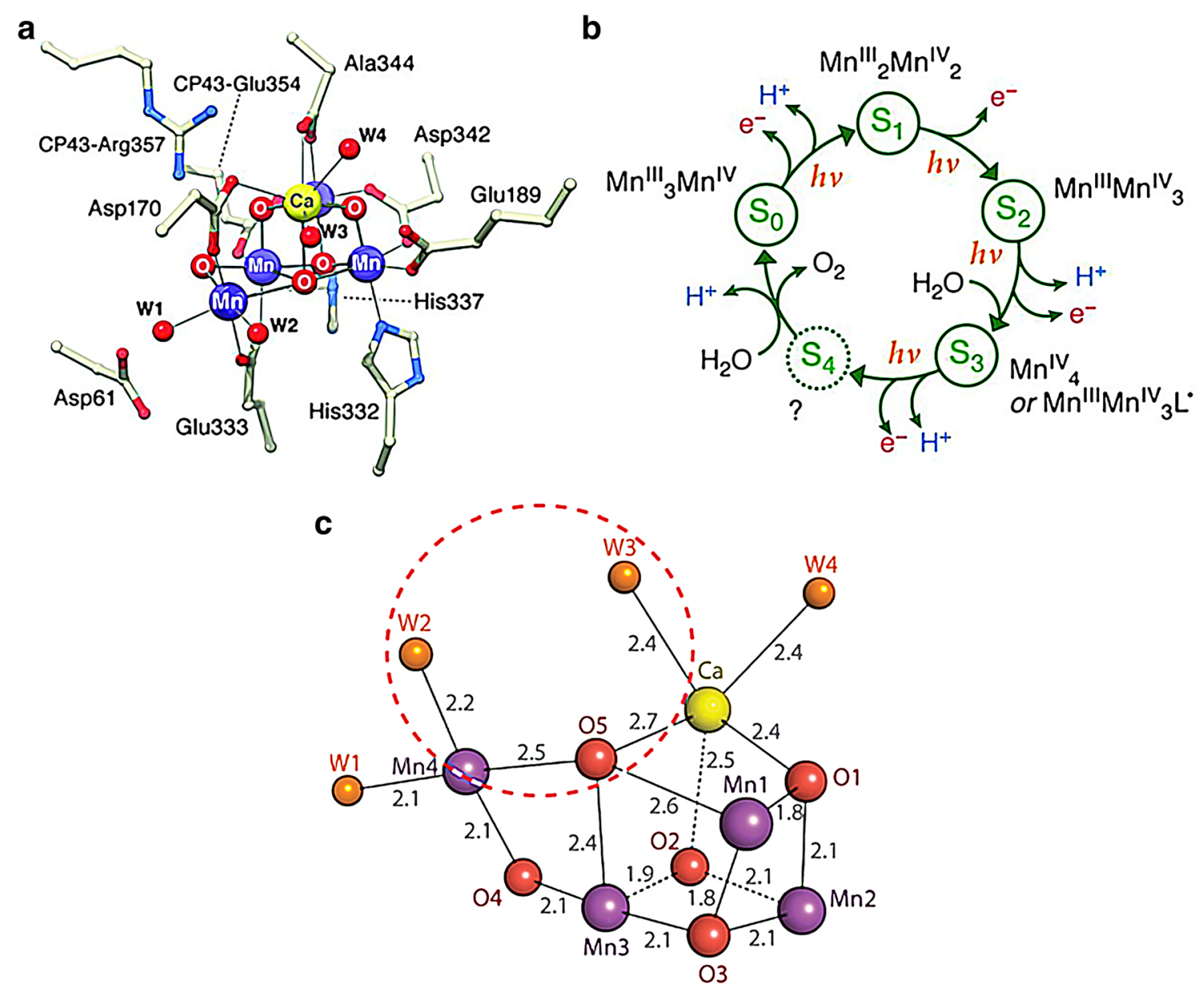

Fig. 1 a Active site structure of the oxygen evolving complex, a $\mathrm{Mn}_{4} \mathrm{O}_{5} \mathrm{Ca}$ cofactor with bond lengths [35]. b The five intermediate "S" states of the reaction cycle, showing the sequence of electron- and proton-removal steps and the likely oxidation states of the Mn ions in each metastable state. Adapted with permission from [35] (Copyright 2014, AAAS the science society publications. c Distances (in Å) between metal atoms and oxo bridges or water molecules [34]. Adapted with permission from [34]. Copyright 2011, Nature publishing group)

water splitting, proceeds through five different states $\mathrm{SO}$ S4 (Kok cycle). After the four sequential oxidation events the OEC advances stepwise through the S0, S1, S2, and $\mathrm{S} 3$ states. When the $\mathrm{S} 3$ state is advanced to the transient S4 state, $\mathrm{O}_{2}$ is spontaneously released and the S0 state is reformed [10, 11, 14, 29-38].

Spectroscopic study and DFT calculations strongly suggesting that the S0 state is the most reduced state in OEC, containing three $\mathrm{Mn}(\mathrm{III})$ and a $\mathrm{Mn}(\mathrm{IV})$ ion in the $\mathrm{Mn}_{4} \mathrm{CaO}_{5}$ cluster and has a ground spin state of $1 / 2$ [4042]. Initially, after the electron transfer cycle the nearby tyrosine radical oxidise one of the $\mathrm{Mn}(\mathrm{III})$ to $\mathrm{Mn}(\mathrm{IV})$ in the $\mathrm{Mn}_{4} \mathrm{CaO}_{5}$ cluster with concomitant proton transfer and the $\mathrm{S} 1$ state contains the Mn oxidation state pattern III, IV, IV, III with spin state of 0 and is diamagnetic [43]. During the second oxidation of the OEC it was observed that no proton is released from the cluster and positive charge is accumulated in the OEC during the transition of $\mathrm{S} 1 \rightarrow \mathrm{S}^{+}[44,45]$. The $\mathrm{S} 2$ state is paramagnetic and has been extensively studied using EPR spectroscopy and two different EPR signal at approximately $g=4.1$ is observed and dramatic multiline EPR signal at $g=2$ is observed based on the conditions used for the EPR measurement [46-51]. The $g=4.1$ and $g=2$ EPR signals represents two spin isomers of the $\mathrm{S} 2$ state with a ground state of $S=5 / 2$ and $S=1 / 2$ respectively. The $M n$ oxidation state pattern is IV, IV, IV, III for $S=5 / 2$ state in which the dangler fourth $\mathrm{Mn}$ ion is five-coordinated with $\mathrm{Mn}(\mathrm{III})$ center and is weakly electronically coupled to the other three Mn(IV) ions in the closed cubane motif. On the other hand, the Mn oxidation state pattern for $S=1 / 2$ state is III, IV, IV, IV in which the Mn1 is a five-coordinated $\mathrm{Mn}$ (III) center and all $\mathrm{Mn}$ ions are connected by di- $\mu$-oxo bridges resulting in short $\mathrm{Mn}-\mathrm{Mn}$ 
distances and promotes antiferromagnetic coupling of the Mn center leading to a low spin state [45, 47, 48, 51]. During the third oxidation of the OEC by the nearby tyrosine radical, the Mn oxidation is coupled with the proton transfer and followed by water coordination and the resulting S3 state's contain four Mn(IV) centers with six-coordination $[35,52,53]$. Based on the coordination of second water molecule on the cluster many different mechanisms have been suggested and formation of S3 from $\mathrm{S} 2$ is still debated. The first mechanism considered the closed cubane $S=5 / 2$ spin isomer and during the oxidation of the Mn4 from $\mathrm{Mn}(\mathrm{III})$ to $\mathrm{Mn}(\mathrm{IV})$, a water molecule (W3) is transferred from Ca to Mn4 and the water from the hydrogen-bonded network surrounding the OEC occupy the site previously occupied by W3 to $\mathrm{Ca}[35,52,53]$. In another mechanism, the open cubane $\mathrm{S}=1 / 2$ spin isomer is considered in which a new water molecule added to $\mathrm{Mn} 1$ when it is oxidized from $\mathrm{Mn}$ (III) to $\mathrm{Mn}(\mathrm{IV})$ followed by deprotonation to form a terminal hydroxo ligand on it (Fig. 2).

Inspired from the ammonia binding studies to the $\mathrm{S} 2$ state another mechanism is suggested [52, 54-58]. During the oxidation of $\mathrm{Mn} 4$ from $\mathrm{Mn}$ (III) to $\mathrm{Mn}(\mathrm{IV})$ a water molecules from $\mathrm{Mn} 4$ is inserted between Mn4 and Mn3 and the water molecule (W1) coordinated to Mn4 center replace the site previously occupied by W2 and a water molecule hydrogen bonded with $\mathrm{O} 4$ around is coordinated to Mn4 in the site occupied by W1 [35, $52,56,59]$. Experimental data for the S4 and the transition of S3 $\rightarrow$ S0 states are limited, however, computational studies are supporting the mechanism of $\mathrm{O}-\mathrm{O}$ bond formation and this transition consist of $\mathrm{O}_{2}$ formation and release along with two protons and binding of a water molecule to the $\mathrm{Mn}_{4} \mathrm{O}_{5} \mathrm{Ca}$ cluster. Two different isoelectronic intermediates species such as $\mathrm{Mn}^{\mathrm{IV}}-\mathrm{O}$. radical or a $\mathrm{Mn}^{\mathrm{V}}=\mathrm{O}$ species are suggested to be involved in the S4 state and their involvement is still debated. An oxo-oxyl radical coupling mechanism for $\mathrm{O}-\mathrm{O}$ bond formation has been supported by extensive computational studies in which the $\mathrm{Mn}^{\mathrm{IV}}-\mathrm{O}$ - radical species couple to a $\mu$-oxo bridge [35, 60-64]. Based on the studies from inorganic water oxidation catalysts, the water-nucleophile attack mechanism for $\mathrm{O}-\mathrm{O}$ bond formation has been suggested in which the highly electrophilic $\mathrm{Mn}^{\mathrm{V}}=\mathrm{O}$ species attack the oxygen on the water [8,65-67]. However, to date, no experimental evidence has been collected to support either the oxo-oxyl radical mechanism or the water-nucleophile attack mechanism in OEC. Even though most of our understanding of $\mathrm{O}-\mathrm{O}$ bond formation arrived from computational studies the chemistry of OEC is supportive in the design of synthetic catalysts for efficient water oxidation reaction. More study on OEC is crucial to understand the mechanism and how OEC stabilised in the protein pocket and utilise the high-valent Mn-oxo intermediates towards hydrogen abstraction and electron transfer reactions in a classy manner to effect the oxygen evolving reaction.

\subsection{Ribonucleotide reductases (RNRs)}

In all organisms, Ribonucleotide reductases (RNRs) are the key enzymes involved in catalysing the conversion of ribonucleotides to deoxyribonucleotides, the precursor for DNA replication and repair. In class-Ib RNR from Corynebacterium ammoniagenes contain a MnMn cofactor and class-Ic RNR from Chlamydia trachomatis $(\mathrm{Ct})$, contain a MnFe cofactor in subunit R2, instead of an FeFe cofactor plus a redox-active tyrosine in class-Ia RNRs $[15-28,66,67]$. The $1.65 \AA$ resolution crystal structure of

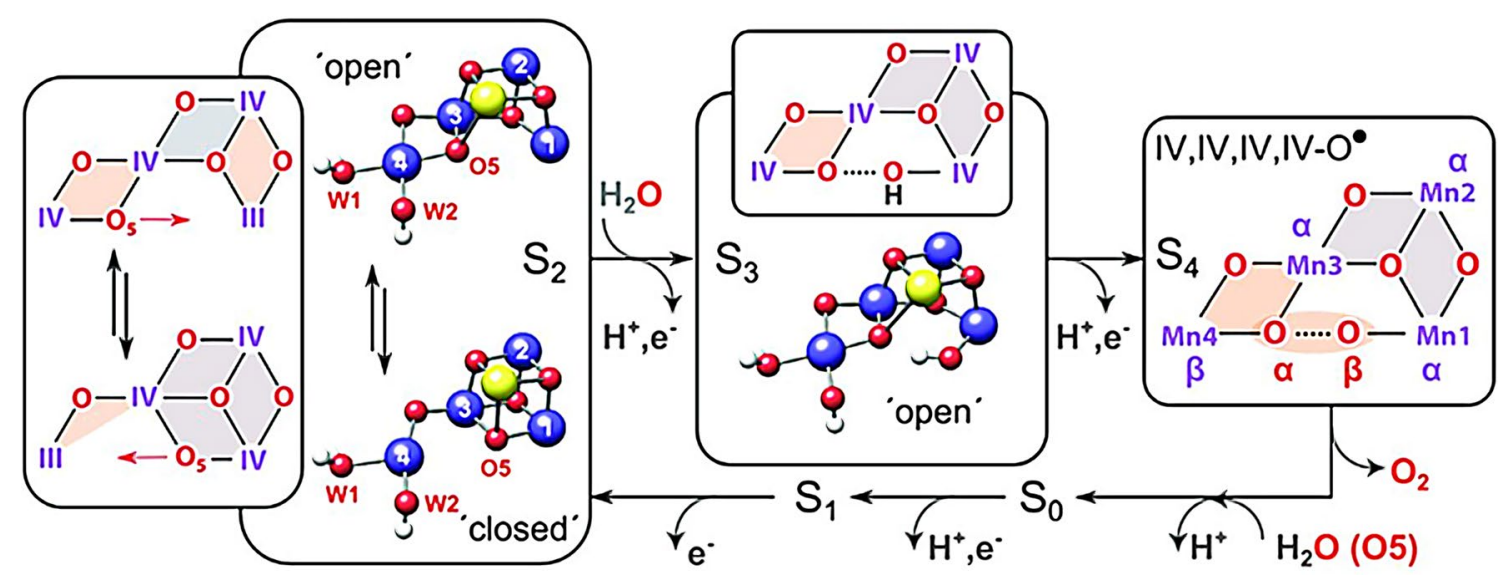

Fig. 2 Theoretically calculated structures for the S2 and S3 states and the proposed mechanism of O-O bond formation (Adapted with permission from [35]. Copyright 2014, AAAS the science society publications) 
$\mathrm{Mn}_{2}^{\mathrm{II}}-\mathrm{NrdF}$ contains one monomer per asymmetric unit with the presence of two $\mathrm{Mn}^{\mathrm{II}}$ sites (Fig. 3) with a MnMn distance of $3.7 \AA$ [23]. Mn1 is coordinated by His101, Asp67 and a terminal water molecule and Mn2 is coordinated by His195 and a terminal water molecule. Three glutamate residues (Glu98, Glu158, and Glu192) bridge the two metals in a manner previously not observed in RNRs and related carboxylate-bridged diiron enzymes $[23,68]$. The location of the two interacting solvent molecules at Mn2 could easily accommodate by molecular oxygen [22]. These waters may dissociate, allowing the oxidant to initially bind terminally to $\mathrm{Mn} 2$ in this position, by analogy to the proposal for $\mathrm{H}_{2} \mathrm{O}_{2}$ binding to the structurally related $\mathrm{Mn}$ catalases [69].

Class Ib with dimanganese cluster participate in the generation of tyrosyl radical in $\mathrm{R} 2$ unit and the reduction of the catalytic site in R1 [70]. However the di-manganese cluster adopts a somewhat similar coordination environment to that of methane monooxygenase hydroxylase unit (MMOH) $[23,25,70]$. Unlike class Ia and Ib, in class Ic the tyrosyl radical site is replaced by a phenylalanine residue and all the carboxyl ligands to the metal ions are substituted by glutamate residues. By use of Mössbauer, EPR and extended X-ray absorption fine structure (EXAFS), it has been shown that in class Ic R2 proteins, a mixed metal center $\mathrm{Mn}^{\mathrm{IV}} / \mathrm{Fe}^{\mathrm{III}}$ is the metal cofactor
[19-22, 71, 72] acting as source of the oxidation catalyst, capable of generating the thiyl radical in $\mathrm{R} 1$.

The mechanism of oxygen activation in the class Ib RNR is derived from EPR spectroscopy along with X-ray crystallography of the protein. RNR utilise oxygen activation mechanism and attain high-valent states and producing tyrosine radical. Two different mechanistic pathways for dimanganese and radical cofactor assembly have been proposed [23-25, 73]. But in both mechanisms the first step involves oxidation of the $\mathrm{Mn}^{\mathrm{II}} / \mathrm{Mn}^{\mathrm{II}}$ to $\mathrm{Mn}^{\mathrm{III}} / \mathrm{Mn}^{\mathrm{III}}$ by $\mathrm{H}_{2} \mathrm{O}_{2}$ is considered. In the second step, the oxo bridged $\mathrm{Mn}^{\mathrm{III}} / \mathrm{Mn}^{\mathrm{III}}$ dimer converted into diamond core $\mathrm{Mn}^{\mathrm{IV}}$ / $\mathrm{Mn}^{\mathrm{IV}}$ intermediate and it is having sufficient oxidizing power to extract one electron and one proton from the tyrosine residue [23-25, 73]. However different coordination mode of the peroxide ligand is proposed. Cox and co-workers suggested that the $\mathrm{HO}_{2}{ }^{-}$or $\mathrm{H}_{2} \mathrm{O}_{2}$ coordinates to both the manganese atoms through only one oxygen atom along with the shift of the bridging carboxylate ligand to produces an oxo-bridged $\mathrm{Mn}^{\mathrm{III}} / \mathrm{Mn}^{\mathrm{III}}$ complex [25]. After that the second $\mathrm{H}_{2} \mathrm{O}_{2}$ replace a water ligand at $\mathrm{Mn}_{\mathrm{a}}$ closest to the tyrosyl radical (Fig. 4) and produce a bridging hydroperoxide species of $\mathrm{Mn}^{\mathrm{III}}-\mathrm{O}-\mathrm{Mn}^{\mathrm{III}}$. The protonation of the bridging hydroperoxide and release a water molecule leading to a second two-electron oxidation process to produce the highly unstable $\mathrm{Mn}^{\mathrm{IV}} / \mathrm{Mn}^{\mathrm{IV}}$ transient species followed by formation of a more stable

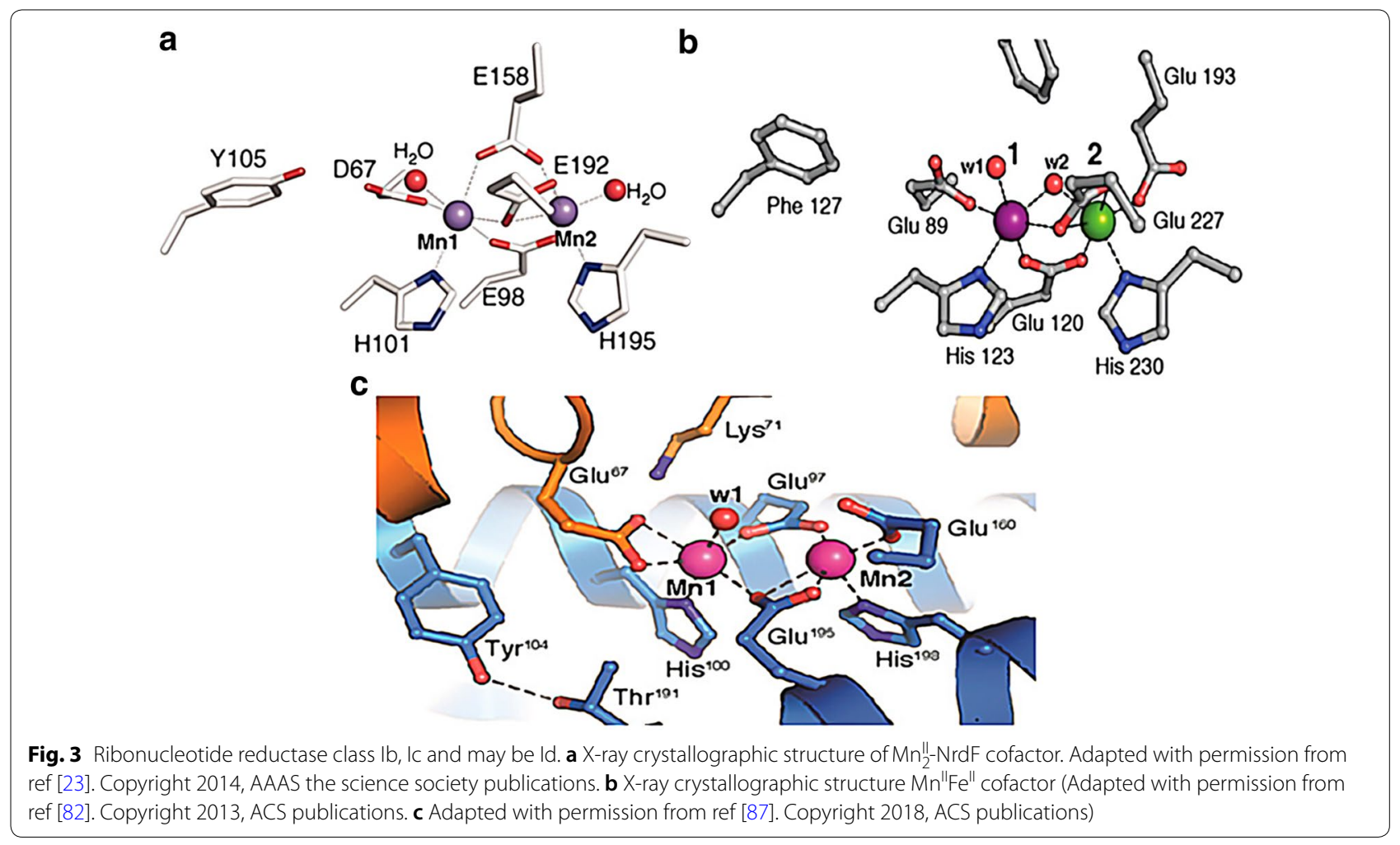




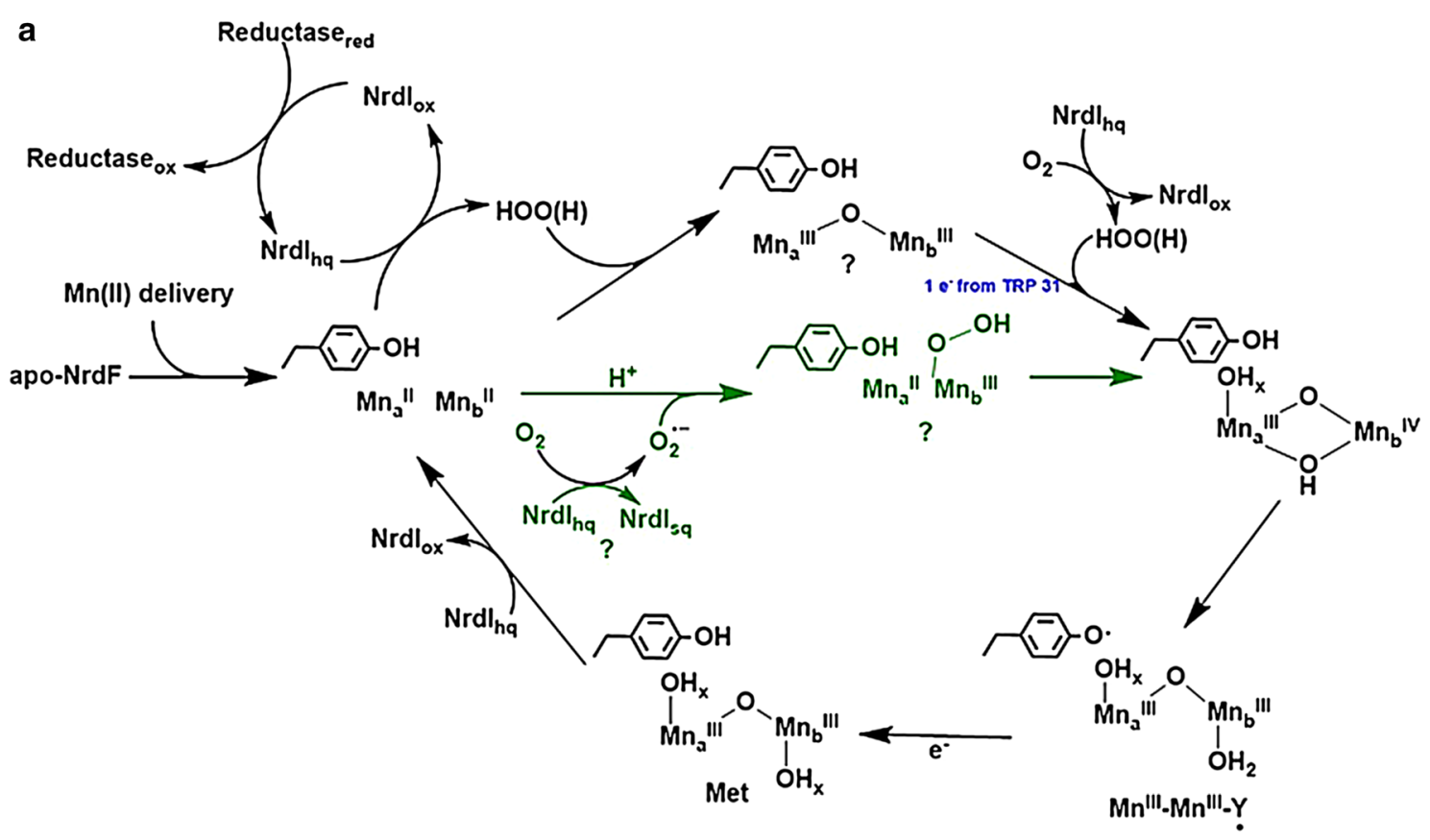

b

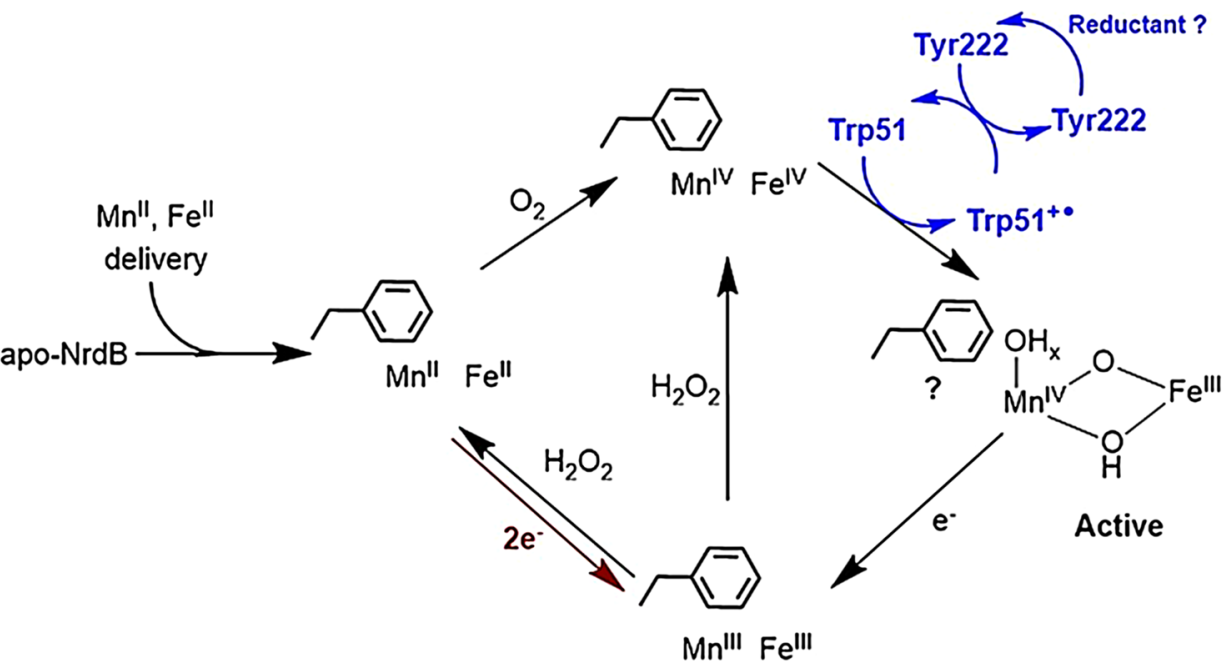

Fig. 4 The proposed reaction cycles for the generation of the tyrosyl radical in a class Ib and $\mathbf{b}$ Ic RNR suggested by Stubbe. Redrawn from ref [73]

$\mathrm{Mn}^{\mathrm{III}} / \mathrm{Mn}^{\mathrm{IV}}$ state by oxidizing a nearby tyrosine residue. Both $\mathrm{Mn}^{\mathrm{IV}} / \mathrm{Mn}^{\mathrm{IV}}$ and $\mathrm{Mn}^{\mathrm{III}} / \mathrm{Mn}^{\mathrm{IV}}$ have the oxidizing power to extract an electron from the tyrosine cofactor [25]. But Cotruvo and Stubbe proposed that $\mathrm{HO}_{2}{ }^{-}$or $\mathrm{H}_{2} \mathrm{O}_{2}$ replaces a water ligand on $\mathrm{Mn}_{\mathrm{b}}$, which is slightly away from the tyrosine radical site and forms a bridging hydroperoxide between the two $\mathrm{Mn}$ (II) ions with concomitant rearrangements of carboxylate oxygen (E202). After that the oxidation of the $\mathrm{Mn}^{\mathrm{III}} / \mathrm{Mn}^{\mathrm{III}}$ cluster by the bound hydroperoxide leads to release of a water molecule to produce the diamond core $\mathrm{Mn}{ }^{\mathrm{III}} / \mathrm{Mn}^{\mathrm{IV}}$ intermediate rather than a $\mathrm{Mn}^{\mathrm{IV}} / \mathrm{Mn}^{\mathrm{IV}}$ intermediate. Also from the crystal structure of the R2F subunit with NrdI cofactor from class Ib E. coli., Cortuvo and Stubbe proposed that the flavodoxin like protein NrdI (NrdIhq) is an essential component for the making the $\mathrm{HO}_{2}{ }^{-}$required in the reaction cycle with di-manganese [23, 24, 69, 72]. Class Ic RNRs also utilise the dimetal cluster but instead of dimanganese in class Ib it is utilising MnFe cluster and producing cysteine radical rather than a tyrosine radical [19-21, 74-86]. In Chlamydia trachomatis (Ct) enzyme the $\mathrm{Mn}^{\mathrm{II}} / \mathrm{Fe}^{\mathrm{II}}$ complex reacts with $\mathrm{O}_{2}$ to form a $\mathrm{Mn}^{\mathrm{IV}} /$ $\mathrm{Fe}^{\mathrm{IV}}$ intermediate followed by one electron reduction to produce $\mathrm{Mn}^{\mathrm{IV}} / \mathrm{Fe}^{\mathrm{III}}$ cofactor, in which the $\mathrm{Mn}^{\mathrm{IV}}$ is the 
oxidant in the active state. The $\mathrm{Mn}^{\mathrm{II}} / \mathrm{Fe}^{\mathrm{II}}$ cofactor can also react with $\mathrm{H}_{2} \mathrm{O}_{2}$ and converted to the to the active $\mathrm{Mn}^{\mathrm{IV}}$ / $\mathrm{Fe}^{\mathrm{III}}$ state in two steps through $\mathrm{Mn}^{\mathrm{III}} / \mathrm{Fe}^{\mathrm{III}}$ and $\mathrm{Mn}^{\mathrm{IV}} / \mathrm{Fe}^{\mathrm{IV}}$ intermediates [77]. At the position of the tyrosine radical center in Ia/b proteins instead the Ic subunits have phenylalanine; and obviously it is considered as the characteristic of this subclass [19-21, 74-82]. Interestingly, a ribonucleotide reductase (RNR) from Flavobacterium johnsoniae (Fj) differs fundamentally from all the class Ia-c RNRs and it is assigned to a new subclass Id. Even though, its active site is similar to class Ib counterparts it does not require the oxidant supplying flavoprotein (NrdI) needed in Ib systems for superoxide $\left(\mathrm{O}_{2}{ }^{-}\right)$activation and it can scavenging the oxidant from solution itself [87]. Interestingly, in all the manganese containing RNR subunits nature utilise the high-valent $\mathrm{Mn}(\mathrm{IV})$ species to initiate the hydrogen abstraction from their counter radical-harbouring domain for the further reaction, in making the biologically important conversion such as deoxyribonucleotide from ribonucleotide. Also based on having with or without the flavoprotein counter part, the $\mathrm{Mn}_{2}$ cofactor activate the active oxygen species or molecular oxygen to carry out the hydrogen atom transfer reaction (HAT).

\subsection{High-valent manganese-oxo intermediates at nano sites}

Natural systems successfully utilise the high-valent manganese-oxo species for robust catalytic oxidation, inspired the scientific community. Several attempts have been made to understand and utilise, the novel strategies employed by the natural system. Numerous reports are available for many different oxidation reactions utilising manganese oxide nano particles in the literature, however, studies which involves the characterisation and mechanism of high-valent Mn-oxo intermediates in the catalytic cycle are scarce. Notably, various kinds of manganese oxide nanoparticles are studied for water oxidation reaction and the importance of the distortion in the mixed valent manganese centers in the $\mathrm{Mn}_{4} \mathrm{CaO}_{5}$ cluster for the oxygen evolution reaction is realised on the surface of the manganese oxide nano particle [88-103].

Kurtz et al. studied the biomimetic oxidation of water and shown that the photocatalytic activity of the calcium manganese(III) oxide hydrates $\left(\mathrm{CaMn}_{2} \mathrm{O}_{4} \cdot \mathrm{xH}_{2} \mathrm{O}\right)$ is superior than the manganese(III) oxide particles $\left(\alpha-\mathrm{Mn}_{2} \mathrm{O}_{3}\right)$ and related the importance of elemental composition of the $\mathrm{Mn}_{4} \mathrm{O}_{\mathrm{x}} \mathrm{Ca}$ core of the OEC in the activity [86]. The Jaramillo group proposed that the higher OER activity of mixed-valence $\mathrm{MnO}_{\mathrm{x}}$ film is depends on the highvalent manganese distribution on the oxide material $[89,90]$. Also, the effect of hetero atom on the catalytic surface are studied in the $\mathrm{MnO}_{\mathrm{x}} / \mathrm{Au}-\mathrm{GC}$ composite, synthesized by adding $\mathrm{Au}$ to $\mathrm{MnO}_{\mathrm{x}}$, displayed a surprisingly high enhancement in catalytic performance compared to pure $\mathrm{MnO}_{\mathrm{x}}$ catalysts [91]. He and Suib group used a similar approach in a photochemical water oxidation of the gold-nanoparticle modified $\mathrm{MnO}_{2}$, evidenced from XANES, addition of a small amount of gold to the $\mathrm{MnO}_{2}$ surface partially reduces the $\mathrm{Mn}$ species to create a mixed valence state thereby enhance the catalytic activity compared to pristine $\mathrm{MnO}_{2}$ [92]. Dau group observed the formation of disordered $\mathrm{Mn}^{\mathrm{IV}} \mathrm{O}_{2}$ motif for high catalytic activity at neutral $\mathrm{pH}$ [93]. Navrotsky group theoretically verified the effect of mixed valence state on OER performance. Also they experimentally demonstrated that among the four different manganese compounds, $\mathrm{CaMnO}, \mathrm{Mn}_{2} \mathrm{O}_{3}, \mathrm{MnO}_{2}$, and $\mathrm{Mn}_{3} \mathrm{O}_{4}$, the mixed-valence $\mathrm{CaMnO}\left(\mathrm{Mn}^{3+}\right.$ and $\left.\mathrm{Mn}^{4+}\right)$ exhibited the highest catalytic activity [94]. Nocera and co-workers reported the oxygen evolution activity of electrodeposited $\mathrm{MnO}_{\mathrm{x}}$ films and explains how the original birnessite-like $\mathrm{MnO}_{\mathrm{x}}\left(\delta-\mathrm{MnO}_{2}\right)$ undergoes disordered phase change during OER cycling to exhibit high activity [95]. The Driess group synthesised an amorphous $\mathrm{MnO}_{\mathrm{x}}$ compound using chemical oxidant ceric ammonium nitrate (CAN) and proposed that the change in oxidation state of the amorphous $\mathrm{MnO}_{\mathrm{x}}$ compared to the initial crystalline $\mathrm{MnO}$ is the key for high reactivity and using EXAFS analysis they insisted that the active site of amorphorized $\mathrm{MnO}_{\mathrm{x}}$ resembles that of the $\mathrm{Mn}_{4} \mathrm{Ca}$ cluster $[96,97]$. They also synthesised amorphous $\mathrm{MnO}_{\mathrm{x}}$ layered $\mathrm{Mn}_{3} \mathrm{~N}_{2}$ particles by molecular approach, in which the layer generated by stepwise oxidation of $\mathrm{Mn}^{2+}$ to $\mathrm{Mn}^{4+}$ and documented as the real active sites. Importantly, they argue that the Jahn-Teller distorted $\mathrm{Mn}-\mathrm{O}$ bonds generated by $\mathrm{Mn}^{3+}$ assisted $\mathrm{Mn}^{4+}$ for binding $\mathrm{O}-\mathrm{O}$ with appropriate strength is facilitating the OER [98]. Our group reported many different manganese oxide materials for OER [99-106], among them the nanosized Mn oxide catalysts display outstanding catalytic activity under neutral conditions [102, 105]. The sub-10 nm-sized monodispersed $\mathrm{MnO}$ nanoparticles showed unexpectedly high OER performance compared to the well-known catalysts $\mathrm{Co}-\mathrm{Pi}$ and $\mathrm{MnO}_{\mathrm{x}}$. The stability of $\mathrm{Mn}^{3+}$ intermediates on the nanosized oxide surface was also significantly improved during catalysis. Very interestingly, we successfully demonstrated that the $10 \mathrm{~nm}$ size $\mathrm{MnO}$ stably generate the $\mathrm{Mn}(\mathrm{III})$ species via proton-coupled electron transfer pathway. Furthermore, we spectroscopically characterised the reaction intermediate $\mathrm{Mn}^{\mathrm{IV}}=\mathrm{O}$ species using in situ UV-Visible and resonance raman analysis during the catalysis (Fig. 5) [105]. Raman spectra of the MnO NPs during electrolysis at constant potentials showing the characteristic $\mathrm{Mn}$ (II)$\mathrm{O}$ stretching vibration $\left(\mathrm{A}_{\mathrm{g}}\right)$ and $\mathrm{Mn}(\mathrm{III})-\mathrm{O}$ stretching $\left(\mathrm{E}_{\mathrm{g}}\right)$ modes as broad shoulder bands around 640 and 

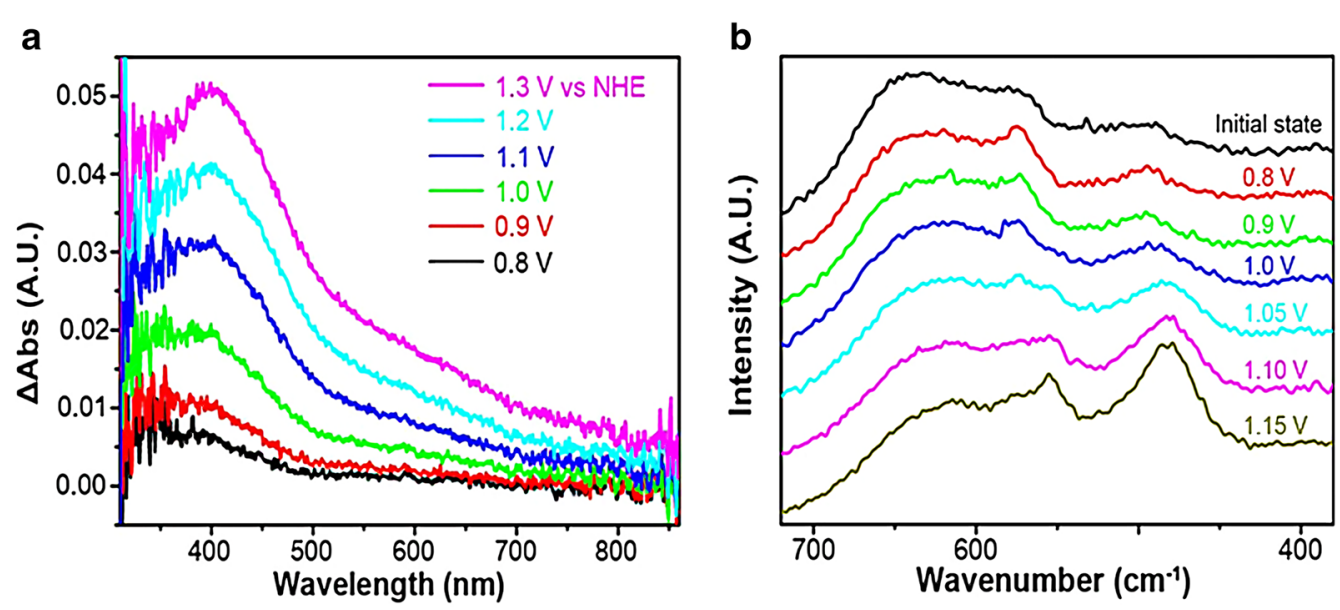

Fig. 5 a In-situ UV-Vis difference spectra of the MnO NPs based on the applied potential. $\mathbf{b}$ /n-situ Raman spectra of the MnO NPs at various potential collected during bulk electrolysis [105] (Adapted with permission from ref [105]. Copyright 2017, ACS publications)

$575 \mathrm{~cm}^{-1}$ respectively. Upon increasing the applied potential to $1.05 \mathrm{~V}$ vs NHE, new Raman peaks appeared at approximately 555 and $480 \mathrm{~cm}^{-1}$, with corresponding decrease in intensity of the $\mathrm{Mn}(\mathrm{III})$-related bands. The shift in the Raman values and relative intensities of the generated peaks were assigned to the stretching vibration of $\mathrm{Mn}(\mathrm{IV})-\mathrm{O}$ species. We also identified the generated reaction intermediates using in situ diffuse transmission UV-vis analysis. Initially, the MnO NPs exhibited two bands in the UV regions at approximately 350 and $380 \mathrm{~nm}$, corresponding to $\mathrm{O}^{2-} \rightarrow \mathrm{Mn}^{\mathrm{II}}$ and $\mathrm{O}^{2-} \rightarrow \mathrm{Mn}^{\mathrm{III}}$ ligand-to-metal charge transfer along with several weak peaks originating from $\mathrm{d}-\mathrm{d}$ transitions in the visible region. Upon increasing the applied potentials at $0.1 \mathrm{~V}$ intervals, two distinct absorption bands in the regions of $400 \mathrm{~nm}$ and $600 \mathrm{~nm}$ were identified. The origins of the peaks were assigned to $\mathrm{Mn}(\mathrm{IV})$ species, by matching with broad peak in the region of $400 \mathrm{~nm}$ and shoulder peaks at approximately 575 and $700 \mathrm{~nm}$ of $\mathrm{Mn}(\mathrm{IV})$ in $\mathrm{MnO}_{2}$ [105]. In most of the water oxidising manganese oxide catalysts the generation of the distorted structure on the surface by generating the mixed valency by various thermal, chemical and electrochemical methods are realised with respect to the OEC in which the incorporation of $\mathrm{Ca}$ ion and mixed valency plays a crucial role in distorting the structure and function the OEC.

1.4 High-valent $\mathrm{Mn}^{\mathrm{IV}}$-oxo Intermediates at Molecular Sites Although manganese is the Nature's choice for the catalytic oxidation of water in photosystem II, there are only a few reports of synthetic manganese compounds which are able to catalyze this reaction. However, various manganese complexes are reported for the oxygen atom transfer (OAT) and hydrogen atom transfer (HAT) reactions and realised the involvement of high-valent $\mathrm{Mn}(\mathrm{IV})$-oxo species in the catalytic cycle. The first characterized mononuclear manganese(IV)-oxo complexes with porphyrinic ligands were reported by Groves and co-workers. The reaction of manganese(III) complex [(TMP) $\left.\mathrm{Mn}^{\mathrm{III}} \mathrm{Cl}\right]$ with peroxy acid produced a stable $\left[(\mathrm{TMP}) \mathrm{Mn}^{\mathrm{IV}} \mathrm{O}\right]$ and $\left[(\mathrm{TMP}) \mathrm{Mn}^{\mathrm{IV}} \mathrm{O}(\mathrm{OH})\right]$ species, capable of transferring their oxo group to olefins to produce epoxides [107-109]. The manganese salen complexes (Jacobsen catalysts) have been extensively studied as catalysts for the oxidation of olefins to the corresponding epoxides, in which they identified the formation of $\left[(\right.$ Salen $\left.) \mathrm{Mn}^{\mathrm{IV}}(\mathrm{O})\right]$ species using EPR and NMR upon interaction of [(Salen)Mn $\left.{ }^{\mathrm{III}}\right]$ with $m$-CPBA or PhIO and proposed as the reactive intermediate involved in the catalytic cycle [110, 111]. Later, Yin and co-workers isolated a non-heme monomeric $\mathrm{Mn}(\mathrm{IV})$-complex $\left[\left(\mathrm{Me}_{2} \mathrm{EBC}\right)\right.$ $\left.\mathrm{Mn}^{\mathrm{IV}}(\mathrm{OH})_{2}\right]^{2+}$ (where $\mathrm{Me}_{2} \mathrm{EBC}=4,11$-dimethyl-1,4,8,11tetrabicyclo[6.2.2]-hexadecane) with two hydroxo ligands and employed as catalysts for epoxidation reaction with and without peroxides [112, 113]. A novel manganese(IV) peroxide intermediate, $\left[\mathrm{Mn}^{\mathrm{IV}}\left(\mathrm{Me}_{2} \mathrm{EBC}\right)\right.$ $(\mathrm{O})(\mathrm{OOH})]^{+}$, was captured as the third kind of active intermediate responsible for epoxidation and the tertbutyl peroxide adduct of this manganese(IV) complex was also detected by mass spectroscopy under catalytic oxidation conditions [114]. Also they studied the $\mathrm{pH}$ dependence HAT reaction rates of the organic substrates (xanthene, fluorene, 1,4-cyclohexadiene, 9,10-dihydroanthracene) using $\mathrm{Mn}^{\mathrm{IV}}(\mathrm{OH})_{2}^{2+}(\mathrm{BDEOH}=83.0 \mathrm{kcal} /$ $\mathrm{mol})$ and $\mathrm{Mn}^{\mathrm{IV}}(\mathrm{O}) \mathrm{OH}^{+}\left(\mathrm{BDE}_{\mathrm{OH}}=84.3 \mathrm{kcal} / \mathrm{mol}\right)$ species and presented a different hydrogen atom abstraction rates [115]. Interestingly, Nam and co-workers reported the first example of reversible $\mathrm{O}-\mathrm{O}$ bond cleavage and 
formation between the in situ generated Mn(IV)-peroxo and $\mathrm{Mn}(\mathrm{V})$-oxo corroles supported by various spectroscopic methods such as UV-vis, EPR, ESI-MS and XAS/ EXAFS analysis [116]. Later they studied the reactivity of various $\mathrm{Mn}(\mathrm{IV})$ species $\left[\mathrm{Mn}^{\mathrm{IV}}(\mathrm{BQCN})(\mathrm{O})\left(\mathrm{H}_{2} \mathrm{O}\right)\right]^{2+}$ (BQCN=N,N'-dimethyl-N, $\mathrm{N}^{\prime}$-bis (8-quinolyl)cyclohexanediamine), $\left[\mathrm{Mn}^{\mathrm{IV}}(\mathrm{OH})_{2}(\mathrm{H}, \mathrm{MePytacn})\right]$ and $\left[\mathrm{Mn}^{\mathrm{IV}}(\mathrm{O})\right.$ $(\mathrm{OH})(\mathrm{H}, \mathrm{MePytacn})]^{+} \quad\left(\right.$ Pytacn $=\mathrm{N}, \mathrm{N}^{\prime}$-dimethyl-N, $\mathrm{N}^{\prime}-$ bis(2-pyridylmethyl)-cyclohexane-trans-1,2-diamine) towards activation of $\mathrm{C}-\mathrm{H}$ bonds of alkyl-functionalized aromatic molecules and the oxidation of aromatic substrates, alkenes and benzyl alcohol [117-120]. The dimerisation of the highly reactive oxo-manganese(IV) complex has been observed in the case of [(Bn-TPEN) $\left.\mathrm{Mn}^{\mathrm{IV}} \mathrm{O}\right]^{2+} \quad\left(\mathrm{Bn}-\mathrm{TPEN}=\mathrm{N}-\right.$ benzyl-N,N, $\mathrm{N}^{\prime} \mathrm{N}^{\prime}$-tris $(2-$ pyridylmethyl)-1,2-diaminoethane) and the HAT reaction of anthracene and anthraquinone also studied [121-124]. Also the effect of non-redox active $\mathrm{Sc}^{3+}$ ion on the stability of the $\mathrm{Mn}(\mathrm{IV})=\mathrm{O}$ species such as $[(\mathrm{Bn}-$ $\left.\mathrm{TPEN}) \mathrm{Mn}^{\mathrm{IV}}(\mathrm{O})\right]^{2+}$ and $\left[(\mathrm{N} 4 \mathrm{Py}) \mathrm{Mn}^{\mathrm{IV}}(\mathrm{O})\right]^{2+}(\mathrm{N} 4 \mathrm{Py}=\mathrm{N}, \mathrm{N}-$ bis(2-pyridylmethyl)- $N$-bis(2-pyridyl)methylamine) are studied and found that the formation of $\mathrm{Mn}^{\mathrm{IV}}(\mathrm{O})-\left(\mathrm{Sc}^{\mathrm{III}}\right)$ complexes and observed that these scandium bound high-valent species catalyse the sulfoxidation of thioanisoles by direct oxygen atom transfer from $\mathrm{Mn}^{\mathrm{IV}}(\mathrm{O})$ complexes whereas without $\mathrm{Sc}^{3+}$ ion involved in electron-transfer reaction rather than OAT [124, 125]. Talsi and coworkers studied the epoxidation of olefins with various oxidants $\left(\mathrm{CH}_{3} \mathrm{CO}_{3} \mathrm{H}\right.$ vs. $m$-CPBA, $t$ - $\mathrm{BuOOH}$ vs. cumyl hydroperoxide, PhIO vs. iodosylmesitylene) using non heme aminopyridinylmanganese(II) complexes $\left[\mathrm{LMn}^{\mathrm{II}}(\mathrm{OTf})_{2}\right]$ as catalysts and high-valent intermediate species $\left[\mathrm{LMn}^{\mathrm{IV}} \mathrm{O}\right]^{2+}$ and $\left[\mathrm{LMn}^{\mathrm{IV}}(\mu-\mathrm{O}){ }_{2} \mathrm{Mn}^{\mathrm{III}} \mathrm{L}\right]^{3+}$ were detected upon the interaction of complex with oxidants by EPR techniques [126]. Feringa et al. studied the mechanism of cis-dihydroxylation and epoxidation of alkenes catalysed dinuclear manganese complex $\left[\mathrm{Mn}_{2}^{\mathrm{IV}}\right.$ $\left.(\mu-\mathrm{O})_{3}(\text { tmtacn })_{2}\right]^{2+}$ with triazacyclononane ligand framework using $\mathrm{H}_{2} \mathrm{O}_{2}$ as mild oxidant [127]. Interestingly, high turnover enantioselective alkene cis-dihydroxylation is achieved with $\mathrm{H}_{2} \mathrm{O}_{2}$ based on the chiral carboxylate ligands on the manganese complexes and the reactivity and selectivity is readily tunable by variation of the carboxylic acid employed. The preference of the $\left[\mathrm{Mn}_{2}^{\mathrm{III}}\right.$ $\left.(\mu-\mathrm{O})\left(\mu-\mathrm{RCO}_{2}\right)_{2}(\text { tmtacn })_{2}\right]^{2+}$ catalyst systems towards electron-rich cis-alkenes with high turnover numbers and efficiency demonstrated that this could be a sustainable and synthetically useful method with $\mathrm{H}_{2} \mathrm{O}_{2}$ as the terminal oxidant $[128,129]$. Similarly the $\mathrm{Mn}(\mathrm{IV})$ complex $\left[\mathrm{Mn}_{2}^{\mathrm{IV}}(\mu-\mathrm{O})_{3}\left(\mathrm{Me}_{3} \mathrm{tacn}\right)_{2}\right]^{2+}$ with substituted ligands can greatly promote the alkene epoxidation efficiency under mild conditions with $\mathrm{H}_{2} \mathrm{O}_{2}$ and identified the active intermediate species $\mathrm{HO}-\mathrm{Mn}^{\mathrm{III}}-(\mu-\mathrm{O})-\mathrm{Mn}^{\mathrm{IV}}=\mathrm{O}$ or $\mathrm{O}=\mathrm{Mn}^{\mathrm{IV}}-(\mu-\mathrm{O})-\mathrm{Mn}^{\mathrm{IV}}=\mathrm{O} \quad$ spectroscopically [130]. Choe et al. explored the catalytic reactivity of di- $\mu$-oxobridged diamond core complexes $\mathrm{Mn}^{\mathrm{III}}-(\mu-\mathrm{O})_{2}-\mathrm{Mn}^{\mathrm{IV}}$ by adding non-redox metal ions to dissociate those dimeric cores and provided clues to understand the mechanism of methane monooxygenase which has a similar diiron diamond core as the intermediate [131]. Kwong et al. detected manganese(IV)-oxo porphyrin upon the reaction of the manganese(III) porphyrin with $\mathrm{PhI}(\mathrm{OAc})_{2}$ and excellent catalytic efficiency with up to $10,000 \mathrm{TON}$ was achieved for epoxidation of olefins and proposed the involvement of manganese $(\mathrm{V})$-oxo intermediate as the premier active oxidant in the catalytic cycle [132]. Recently, Dai et al., demonstrated that manganese complex with a porphyrin-like ligand catalyzes the highly chemoselective and enantioselective oxidation of heteroaromatic sulphides with hydrogen peroxide in good to excellent yields with very high enantioselectivities (up to $90 \%$ yield and up to $>99 \%$ ee) and proposed high-valent $\mathrm{Mn}^{\mathrm{IV}}$-O radical as the reactive oxidant in the catalytic cycle [133]. Shulpin and coworkers reported the efficient oxygenation of alkanes with $\mathrm{H}_{2} \mathrm{O}_{2}$ catalysed by a binuclear manganese(IV) complex $\left[\mathrm{Mn}_{2} \mathrm{~L}_{2} \mathrm{O}_{3}\right]^{2+}(\mathrm{L}=1,4,7$-trimethyl-1,4,7-triazacyclo-nonane) with carboxylic acid as a co-catalyst. The transformation of alkane into the corresponding alkyl hydroperoxide proceeds via generation of alkyl radicals whichis rapidly react with atmospheric molecular oxygen [134]. Also the catechol oxidase activity involves HAT by the high-valent bis(oxo)-bridged manganese(IV) complex reported by Mondal group [135]. High-valent $\mathrm{Mn}(\mathrm{IV})$-oxo intermediates mediated oxidation reactions such as epoxidation and cis-dihydroxylation of olefins, alkane oxidation, sulphoxidation and hydrogen abstraction are realised in many molecular systems and in some cases it is promising, however the issues such as stability and selectivity and use of strong oxidant are to be solved for the real industrial application of these molecular systems.

\subsection{High-valent $\mathrm{Mn}^{\mathrm{v}}$-oxo Intermediates at Molecular Sites}

The $\mathrm{Mn}^{\mathrm{V}}=\mathrm{O}$ species are considered to be involved in many HAT and OAT reactions during the reaction with manganese(III) complexes with dioxygen or oxidants such as hydrogen peroxide $\left(\mathrm{H}_{2} \mathrm{O}_{2}\right)$ or tert-butylhydrogenperoxide $(t-\mathrm{BuOOH})$ or $m$-chloroperbenzoic acid ( $m$-CPBA) and substrate (Table 2). Initially, Kochi group studied the catalytic activity of the various substituted $\mathrm{Mn}^{\mathrm{III}}$ (salen) complexes with iodosylbenzene (PhIO) towards alkenes and studied the interaction by uv-visible spectroscopy [136]. Even though they proposed the involvement of $\mathrm{Mn}^{\mathrm{V}}=\mathrm{O}$ species in the catalytic activity there were no solid evidence has been collected. Collins group generated and characterised the first stable 
Table 2 List of $\mathrm{Mn}^{\mathrm{V}}=\mathbf{O}$ species generated and characterised with different ligands

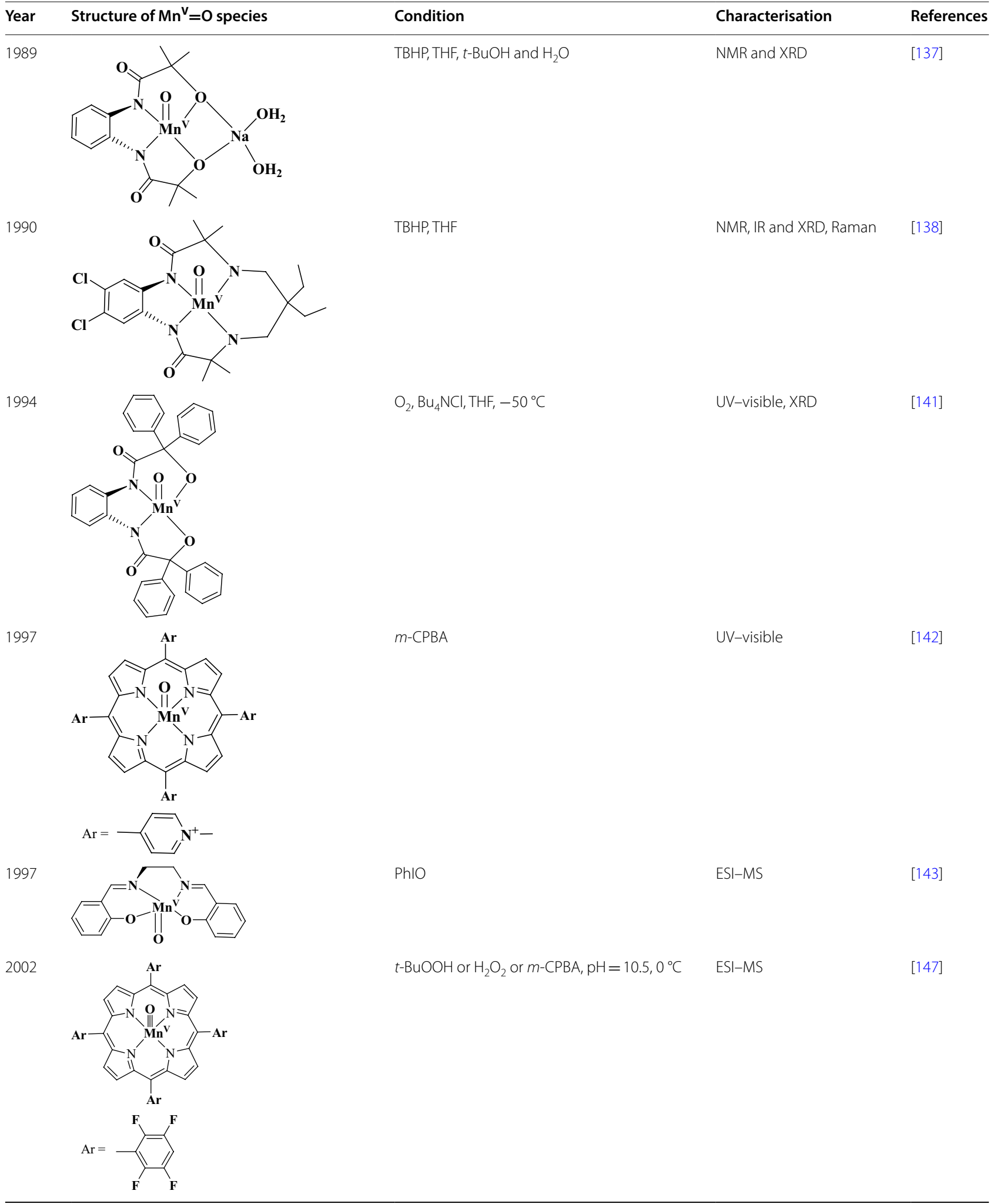


Table 2 (continued)

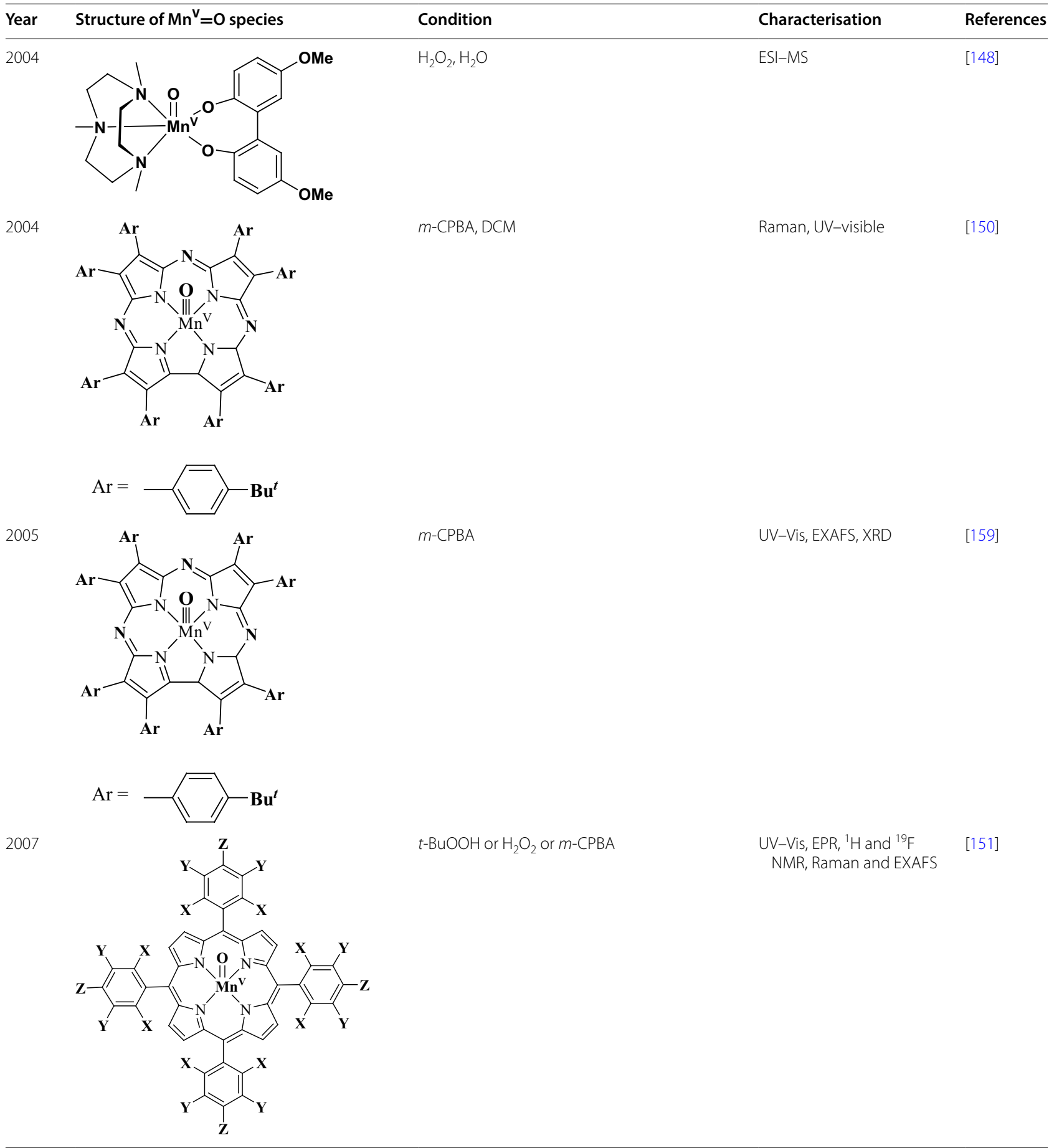


Table 2 (continued)

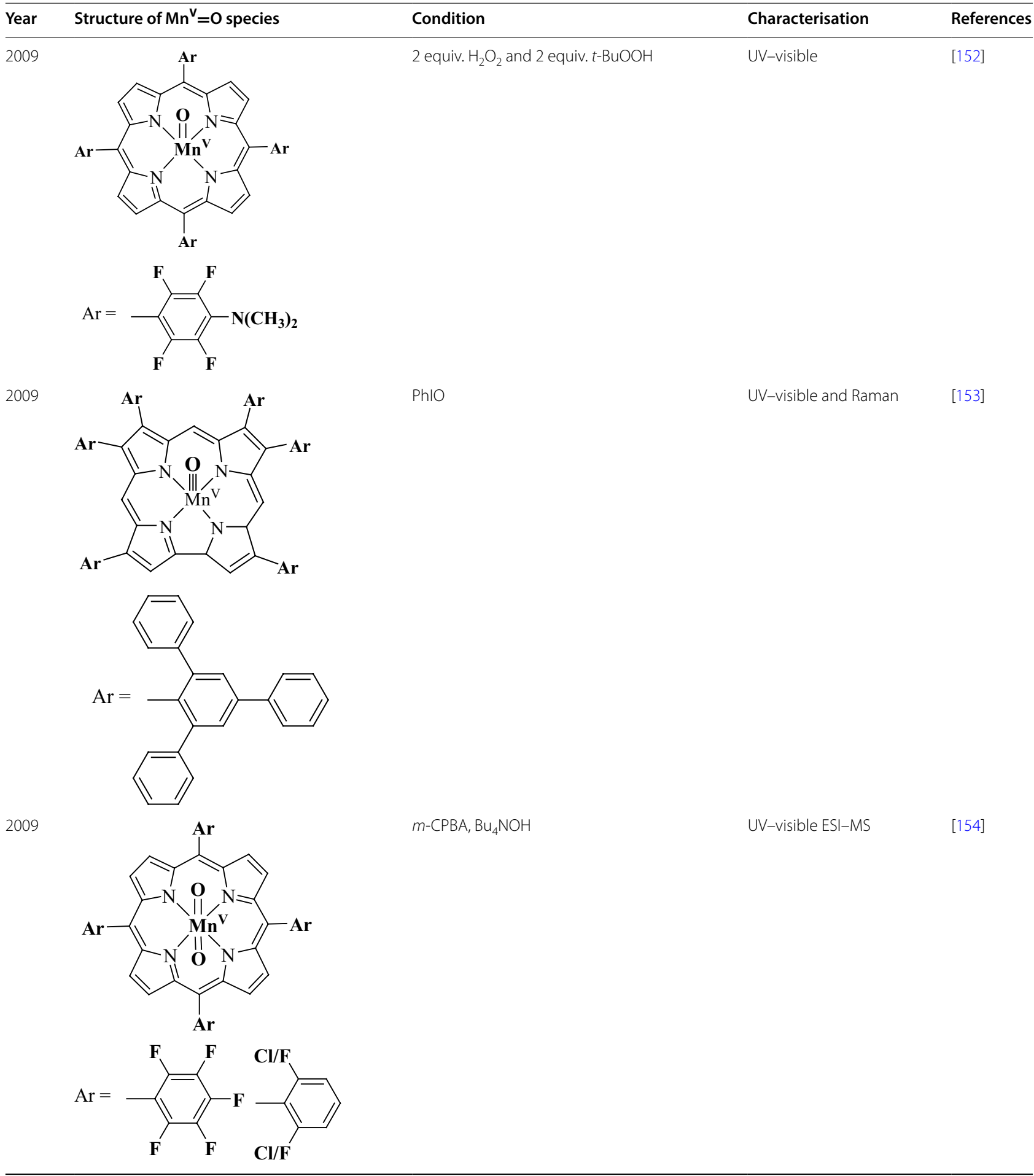


Table 2 (continued)

\begin{tabular}{lll}
\hline Year Structure of $\mathrm{Mn}^{\mathrm{V}=0}$ species & Condition & Characterisation \\
\hline 2012 & {$[\mathrm{FeCp}]^{+}, \mathrm{THF} / \mathrm{DMF}-80^{\circ} \mathrm{C}$} & References \\
{$[67]$}
\end{tabular}

oxomanganese $(\mathrm{V})$ complex by utilising a tetra-anioic ligands with two amido nitrogens and two alkoxide oxygen donors and upon reaction of the $\mathrm{Mn}$ (III) complex with $t-\mathrm{BuOOH}$ and found that the high-valent species are not stable in water [137]. Followed by these study the same group generated another $\mathrm{Mn}(\mathrm{V})=\mathrm{O}$ species with tetraamido ligands which is stable in water and characterised by XRD and IR and Raman studies. However, the $\mathrm{Mn}^{\mathrm{V}}=\mathrm{O}$ species is stable at room temperature and do not undergo oxygen-atom-transfer reactions possessing diamagnetic (low-spin $\mathrm{d}^{2}$ configuration) configuration [138]. Later on, Jacobsen group reported the manganese salentype catalysts for the asymmetric epoxidation of unfunctionalized olefins with $\mathrm{PhIO}$ as oxidant with moderate enantioselectivities for a few substrates (e.g. trans-alkenes, terminal alkenes) and proposed the involvement of $\mathrm{Mn}(\mathrm{V})=\mathrm{O}$ species [139]. In 1992 Collins group again characterised the $\mathrm{Mn}(\mathrm{V})=\mathrm{O}$ species by using isotopic labelling and Raman spectroscopic studies [140]. ƠHalloran group generated the high-valent $\mathrm{Mn}(\mathrm{V})=\mathrm{O}$ species along with hydroxylated solvent molecules upon reaction of the tetraanionic $\mathrm{Mn}$ (III) complex with molecular oxygen and they also characterised the species using UV-visible spectroscopy [141]. In the year of 1997, Groves and co workers reported the successful characterisation of $\mathrm{Mn}(\mathrm{V})=\mathrm{O}$ species using substituted porphyrin ligands and $m$-CPBA and observed a characteristic signal in UV-visible spectroscopy [142]. Plattner et al. first time observed the direct evidence for the involvement of high-valent $\mathrm{Mn}(\mathrm{V})=\mathrm{O}$ species towards OAT of olefins and sulphides by reaction of $\mathrm{Mn}$ (salen) complexes with $m$-CPBA and confirmed by electrospray tandem mass spectrometry [143]. In 1998, Collins again reported the reactivity of the $\mathrm{Mn}(\mathrm{V})=\mathrm{O}$ complexes of tetraamido ligands in which they activated the sluggish complexes by adding alkali and alkaline earth secondary metal ions and observed OAT towards olefins [144]. However, Groves observed that addition of sodium nitrite to the low-spin, $\mathrm{d} 2$ oxo- $\mathrm{Mn}(\mathrm{V})$ species leads to the formation of high-spin $\mathrm{Mn}(\mathrm{IV})$ and $\mathrm{Mn}(\mathrm{III})$ states in which an electron is promoted from $d x y$ to $d(x z, y z)$ because of the vibronic effect due to the elongation of the very short Mn-oxo bond upon reduction [145]. Also they observed the rapid and reversible oxygen atom transfer from the $\mathrm{Mn}(\mathrm{V})$-oxo species to bromide ion [146]. Talsi et al. extensively studied and characterised the $\mathrm{Mn}(\mathrm{IV} /$ $\mathrm{V})=\mathrm{O}$ species of $\mathrm{Mn}$ (salen) complexes generated with various oxidants using NMR and EPR techniques [110]. Nam et al. isolated oxomanganese(v) porphyrin intermediate with $\mathrm{H}_{2} \mathrm{O}_{2}$, in buffered aqueous solution and demonstrated as active epoxidizing intermediate in the catalytic epoxidation of olefins. Interestingly they observed the $\mathrm{pH}$ dependence of the $\mathrm{O}-\mathrm{O}$ bond cleavage in the mechanism with various hydroperoxides [147]. The intermediate $\mathrm{Mn}^{\mathrm{V}}=\mathrm{O}$ species generated from the corresponding $\mathrm{Mn}(\mathrm{III})$ complex with $\mathrm{H}_{2} \mathrm{O}_{2}$ has been identified with $\mathrm{Me}_{3}$ TACN ligands using ESI-MS and studied their role in HAT reactions of phenols as 
one-electron reductants by Oakes group [148]. After that Collman group studied the stereoselectivity of olefin epoxidation catalyzed by $\mathrm{Mn}^{\mathrm{III}}$ (salen) complexes in the presence of neutral donor ligands, employing various iodosylarenes (ArIO: PhIO, $\mathrm{C}_{6} \mathrm{~F}_{5} \mathrm{IO}$, and MesIO) as the oxygen atom source and single $\mathrm{Mn}^{\mathrm{V}}$ (salen)-oxo species is considered to be involved as the sole oxygenating intermediate [149]. Goldberg and co-workers successfully generated the high-valent $\mathrm{Mn}^{\mathrm{V}}=\mathrm{O}$ species upon reaction of the Mn(III) Triazacorrole complex with PhIO and utilised first time for the sulphoxidation of thiols [150]. In 2007, Nam group generated the $\mathrm{Mn}^{\mathrm{V}}=\mathrm{O}$ generated with $\mathrm{Mn}(\mathrm{III})$-porphyrin and $\mathrm{PhIO}$ and characterized with various spectroscopic techniques such as UV-vis, EPR, ${ }^{1} \mathrm{H}$ and ${ }^{19} \mathrm{~F}$ NMR, resonance Raman, and X-ray absorption spectroscopy and found that it is not active towards olefins but involved in OAT of thioanisole and triphenylphosphine [151]. The same group again generated both $\mathrm{Mn}^{\mathrm{V}}-$ and $\mathrm{Mn}^{\mathrm{IV}}$-oxo porphyrins in basic aqueous solution and investigated their reactivities in $\mathrm{C}-\mathrm{H}$ bond activation of hydrocarbons. Also they found that the $\mathrm{C}-\mathrm{H}$ bond breaking ability of $\mathrm{Mn}^{\mathrm{V}}$-oxo complex is 150 times faster than that of a $\mathrm{Mn}^{\mathrm{IV}}$-oxo complex in the oxidation of xanthenes [152]. Chang group synthesised the $\mathrm{Mn}^{\mathrm{V}}=\mathrm{O}$ species of highly bulky bis-pocket corrole 5,10,15-tris(2,4,6-triphenylphenyl)corrole $\quad\left(\mathrm{H}_{3}\right.$ TTPPC) with $\mathrm{PhIO}$ and characterised the triply bonded $\mathrm{Mn} \equiv \mathrm{O}$ moiety by Resonance Raman spectroscopy in manganese $(\mathrm{V})$-oxo complex and performed the direct oxygen atom transfer from (TTPPC) $\mathrm{Mn} \equiv \mathrm{O}$ to styrene confirmed by an ${ }^{18} \mathrm{O}$-labeling experiment. The (TTPPC) $\mathrm{Mn}^{\mathrm{III}}$ complex also exhibits significant shape selectivity in the catalytic epoxidation of nonconjugated dienes [153]. Later for the first time trans-dioxomanganese(V) porphyrin complexes have been synthesized by Nam group and employed successfully for hydride transfer from dihydronicotinamide adenine dinucleotide (NADH) analogues proceeds via proton-coupled electron transfer, followed by rapid electron transfer [154]. Goldberg isolated the high-valent metal-oxo and metal-imido complexes manganese corrolazines $\left(\mathrm{TBP}_{8} \mathrm{Cz}\right) \mathrm{Mn}^{\mathrm{V}}(\mathrm{O})$ and $\left(\mathrm{TBP}_{8} \mathrm{Cz}\right) \mathrm{Mn}^{\mathrm{V}}$ (NMes) and employed as catalysts for epoxidation of alkenes with ArIO oxidants In which the metal-imido complex is a rare example of oxygen atom transfer catalyst and these reactions likely proceed via an unusual ArIO-metal-oxo/imido intermediate [155]. Interestingly, Fukuzumi et al. generated the $\mathrm{Mn}^{\mathrm{V}}=\mathrm{O}$ species by using $\left[\mathrm{Ru}(\mathrm{bpy})_{3}\right]^{3+}$ as electron transfer agent and water as oxidant and catalyses alkenes and alkanes and produced epoxides and diols and aldehydes [156]. For the first time Borovik group generated the high-spin oxomanganese $(\mathrm{V})$ species in a trigonal geometry unlike the other low-spin species in tetragonal geometry and characterised by EPR spectroscopy. The high-spin oxomanganese $(\mathrm{V})$ complex formulation and oxidation reaction with $\left[\mathrm{FeCp}_{2}\right]^{+}$were monitored using optical and EPR spectroscopies [67]. Goldberg studied the effect of lewis acid Addition of anionic donors to the manganese $(\mathrm{V})$-oxo corrolazine complex $\mathrm{MnV}(\mathrm{O})$ $(\mathrm{TBP} 8 \mathrm{Cz})$ has a dramatic influence on oxygen-atom transfer (OAT) reactivity with thioether substrates provides new, fundamental insights regarding the influence of axial donors on high-valent $\mathrm{Mn}^{\mathrm{V}}(\mathrm{O})$ porphyrinoid complexes. Lei et al. generated the iodosylarene metalloporphyrin adducts and manganese(V)-oxo porphyrin species as a cytochrome P450 analogue and studied the mechanism of OAT with cis-stibene using UV-visble and ESI-MS analysis [157]. Interestingly, Goldberg activated the high-valent $\mathrm{Mn}^{\mathrm{V}}=\mathrm{O}$ species of corrolazine using non-metallic lewis acid and axial coordination of the anions for the high reactivity towards thioethersubstrates $[158,159]$. Interestingly, Neumann observed the formation of $\mathrm{O}_{2}$ in water catalysed by a polyfluorooxometallate with $\mathrm{Mn}(\mathrm{IV})-\mathrm{OH}$ and $\mathrm{Mn}(\mathrm{V})-\mathrm{OH}$ center confirmed by EXAFS measurement [160]. Recently, Nam group successfully generated the mononuclear non-heme manganese $(\mathrm{V})$-oxo complex $\left[\mathrm{Mn}^{\mathrm{V}}(\mathrm{O})(\mathrm{TAML})\right]^{-}$synthesized by activating dioxygen in the presence of olefins with weak allylic $\mathrm{C}-\mathrm{H}$ bonds confirmed by various spectroscopic and crystallographic analysis. Also, they studied the interaction of a $\mathrm{Mn}(\mathrm{V})$-oxo complex with $\mathrm{Sc}^{3+}$ ion and found that the binding site of the $\mathrm{Sc}^{3+}$ ion is TAML ligand not the Mn-O moiety [161]. Hayashi group studied the myoglobin reconstituted with a manganese porphycene and found that the engineered myoglobin serves as an artificial metalloenzyme for inert $\mathrm{C}-\mathrm{H}$ bond activation such as oxidation of ethyl benzene via a highvalent $\mathrm{Mn}^{\mathrm{V}}=\mathrm{O}$ species similar to the species employed by native monooxygenases such as cytochrome P450A [162]. Very recently, Goldberg reported the hydrogen atom transfer reactivity of the $\mathrm{Mn}^{\mathrm{V}}=\mathrm{O}$ species with phenol and also they identified the generation of $\mathrm{Mn}^{\mathrm{IV}}-\mathrm{OH}$ species in the pathway of formation of the final $\mathrm{Mn}(\mathrm{III})$ $\mathrm{OH}_{2}$ complex by abstraction of stepwise abstraction of two hydrogen atoms [163].

\section{Conclusion and perspectives}

In this review, recent developments in natural systems operating high-valent Mn-oxygen intermediates for the catalytic reactions are focussed and how their inspiration are realised in nano and molecular levels are discussed. In OEC and ribonucleotide reductases high-valent $\mathrm{Mn}$ oxo intermediate catalyse the $\mathrm{O}-\mathrm{O}$ bond formation or radical generation respectively. In both the natural catalysts the active sites are stabilised by ligands from protein side chains which dictate the overall mechanism and 
stabilise the high-valent Mn-oxo intermediates to achieve the high activity and selectivity of the reaction. Inspired from these processes, as presented in the review several artificial systems have been synthesised and utilised for different oxidation reactions in which the oxygen atom transfer (OAT) or hydrogen atom transfer (HAT) mechanism is suggested. However, the stability and selectivity of the synthetic complexes are necessarily to be improved to overcome the stability issues and its catalytic function to the level of industrial production of energy and other organic materials. Inspired from the natural system, the heterobimetallic approach should be considered to induce high-level distortion in the active site to mimicking the function of the OEC and should be extended to various oxidation reactions. Only $\mathrm{Mn}^{\mathrm{IV}}=\mathrm{O}$ species are realised in nano particles however OEC complex using either $\mathrm{Mn}^{\mathrm{IV}}-\mathrm{O}$. or $\mathrm{Mn}^{\mathrm{V}}=\mathrm{O}$ species for the $\mathrm{O}-\mathrm{O}$ bond formation. So the realisation of these species and use of $\mathrm{Mn}^{\mathrm{IV}}=\mathrm{O}$ or $\mathrm{Mn}^{\mathrm{V}}=\mathrm{O}$ species for various OAT and HAT reactions on the manganese oxide nano particles should be considered, so that the strategies learned from the natural systems to be successfully applied for the real application of the mankind.

\section{Authors' contributions}

MB: Written 1. Introduction part, 3.3. High-valent $\mathrm{Mn}^{\mathrm{IV}}$-oxo Intermediates at Molecular Sites and compilation of the whole manuscript. NS: Written the 3.2. High-valent $\mathrm{Mn}^{\mathrm{IV}}$-oxo Intermediates at Molecular Sites part. HH: Written the 3.1. High-valent Mn-oxo Intermediates at nano sites part. YHL: Written the 3.1. High-valent Mn-oxo Intermediates at nano sites part. All authors read and approved the final manuscript.

\section{Acknowledgements}

Not applicable.

\section{Competing interests}

The authors declares that they have no competing interests.

\section{Availability of data and materials}

Not applicable.

\section{Funding}

This review was supported by Basic Science Research Program (2017R1A2B3012003) which is funded by the National Research Foundation (NRF) under the Ministry of Science, ICT and Future Planning (MSIP), South Korea and the KIST Institutional Program (2V06170).

\section{Publisher's Note}

Springer Nature remains neutral with regard to jurisdictional claims in published maps and institutional affiliations.

Received: 3 May 2018 Accepted: 19 June 2018

Published online: 04 July 2018

\section{References}

1. V.L. Pecoraro, M.J. Baldwin, A. Gelasco, Interaction of manganese with dioxygen and its reduced derivatives. Chem. Rev. 94, 807-826 (1994)

2. R. Manchanda, G.W. Brudvig, R.H. Crabtreee, High-valentoxomanganese clusters: structural and mechanistic work relevant to the oxygen-evolving center in photosystem II. Coord. Chem. Rev. 144, 1-38 (1995)

3. G.C. Dismukes, Manganese enzymes with binuclear active sites. Chem. Rev. 96, 2909-2926 (1996)

4. C.F. Yocum, V.L. Pecoraro, Recent advances in the understanding of the biological chemistry of manganese. Curr. Opin. Chem. Biol. 3, 182-187 (1999)

5. W. Zhu, N.G.J. Richards, Biological functions controlled by manganese redox changes in mononuclear Mn-dependent enzyme. Essays Biochem. 61, 259-270 (2017)

6. D.F. Leto, T.A. Jackson, Peroxomanganese complexes as an aid to understanding redox-active manganese enzymes. J. Biol. Inorg. Chem. 19, 1-15 (2014)

7. V.K. Yachandra, S.K. Klein, Manganese cluster in photosynthesis: where plants oxidize water to dioxygen. Chem. Rev. 96, $2927-2950$ (1996)

8. J.P. McEvoy, G.W. Brudvig, Water-splitting chemistry of photosystem II. Chem. Rev. 106, 4455-4483 (2006)

9. N. Cox, J. Messinger, Reflections on substrate water and dioxygen formation. Biochim. Biophys. Acta 1827, 1020-1030 (2013)

10. N. Cox, D.A. Pantazis, F. Neese, W. Lubitz, Biological water oxidation. Acc. Chem. Res. 46, 1588-1596 (2013)

11. J. Yano, V. Yachandra, $\mathrm{Mn}_{4} \mathrm{Ca}$ cluster in photosynthesis: where and how water is oxidized to dioxygen. Chem. Rev. 114, 4175-4205 (2014)

12. J.R. Shen, The structure of photosystem II and the mechanism of water oxidation in photosynthesis. Annu. Rev. Plant Biol. 66, 23-48 (2015)

13. M. Perez-Navarro, N.F. Lubitz, D.A. Pantazis, N. Cox, Recent developments in biological water oxidation. Curr. Opin. Chem. Biol. 31, 113-119 (2016)

14. D.J. Vinyard, Brudvig progress toward a molecular mechanism of water oxidation in photosystem II. Annu. Rev. Phys. Chem. 68, 101-116 (2017)

15. A. Jordan, P. Reichard, Ribonucleotide reductases. Annu. Rev. Biochem. 67, 71-98 (1998)

16. A. Willing, H. Follmann, G. Auling, Ribonucleotide reductase of brevibacterium-ammoniagenes is a manganese enzyme. Eur. J. Biochem. 170, 603-611 (1996)

17. Y. Huque, F. Fieschi, E. Torrents, I. Gibert, R. Eliasson, The active form of the R2F protein of class Ib ribonucleotide reductase from Corynebacterium ammoniagenes is a diferric protein. J. Biol. Chem. 275, 2536525371 (2000)

18. P. Nordlund, P. Reichard, Ribonucleotide reductases. Annu. Rev. Biochem. 75, 681-706 (2006)

19. W. Jiang, L.M. Hoffart, C. Krebs, J.M. Bollinger, Amanganese(IV)/iron(IV) intermediate in assembly of the manganese(IV)/iron(III) cofactor of Chlamydia trachomatis ribonucleotide reductase. Biochemistry 46, 8709-8716 (2007)

20. W. Jiang, D. Yun, L. Saleh, E.W. Barr, G. Xing, L.M. Hoffart, M.A. Maslak, C. Krebs, J.M. Bollinger, A manganese(IV)/iron(III) cofactor in chlamydia trachomatis ribonucleotide reductase. Science 316, 1188-1191 (2007)

21. W. Jiang, J.M. Bollinger, C. Krebs, The active form of chlamydia trachomatis ribonucleotide reductase R2 protein contains a heterodinuclear $\mathrm{Mn}(\mathrm{IV}) / \mathrm{Fe}(\mathrm{III})$ cluster with $\mathrm{S}=1$ ground state. J. Am. Chem. Soc. 129 7504-7505 (2007)

22. N. Voevodskaya, F. Lendzian, A. Ehrenberg, A. Graslund, A High catalytic activity achieved with a mixed manganese-iron site in protein R2 of Chlamydia ribonucleotide reductase. FEBS Lett. 581, 3351-3355 (2007)

23. A.K. Boal, J.A. Cotruvo, J. Stubbe, A.C. Rosenzweig, Structural basis for activation of class lb ribonucleotide reductase. Science 329, 1526-1530 (2010)

24. J.A. Cotruvo, J. Stubbe, An active dimanganese(III)-tyrosyl radical cofactor in Escherichia coli class Ib ribonucleotide reductase. Biochemistry $\mathbf{4 9}$ 1297-1309 (2010)

25. N. Cox, H. Ogata, P. Stolle, E. Reijerse, G. Auling, A tyrosyl dimanganese coupled spin system is the native metalloradical cofactor of the R2F subunit of the ribonucleotide reductase of Corynebacterium ammoniagenes. J. Am. Chem. Soc. 132, 11197-11213 (2010)

26. Y. Zhang, J. Stubbe, Bacillus subtilis class Ib ribonucleotide reductase is a dimanganese(III)-tyrosyl radical enzyme. Biochemistry 50, 5615-5623 (2011)

27. A.B. Tomter, G. Zoppellaro, C.B. Bell, A.L. Barra, N.H. Andersen, Spectroscopic studies of the iron and manganese reconstituted tyrosyl radical 
in Bacillus Cereus ribonucleotide reductase R2 protein. PLoS ONE 7, e33436 (2012)

28. O. Makhlynets, A.K. Boal, D.V. Rhodes, T. Kitten, A.C. Rosenzweig, J. Stubbe, Streptococcus sanguinis class Ib ribonucleotide reductase high activity with both iron and manganese cofactors and structural insights. J. Biol. Chem. 289, 6259-6272 (2014)

29. A. Zouni, H.T. Witt, J. Kern, P. Fromme, N. Krauss, W. Saenger, P. Orth, Crystal structure of photosystem II from Synechococcus elongatus at 3.8 Å resolution. Nature 409, 739-743 (2001)

30. K.N. Ferreira, T.M. Iverson, K. Maghlaoui, J. Barber, S. Iwata, Architecture of the photosynthetic oxygen-evolving center. Science 303, 1831-1838 (2004)

31. B. Loll, J. Kern, W. Saenger, A. Zouni, J. Biesiadka, Towards complete cofactor arrangement in the $3.0 \AA$ resolution structure of photosystem II. Nature 438, 1040-1044 (2005)

32. A. Guskov, J. Kern, A. Gabdulkhakov, M. Broser, A. Zouni, W. Saenger, Cyanobacterial photosystem II at 2.9-Å resolution and the role of quinones, lipids, channels and chloride. Nat. Struct. Mol. Biol. 16, 334-342 (2009)

33. K. Kawakami, Y. Umena, N. Kamiya, J.R. Shen, Location of chloride and its possible functions in oxygen-evolving photosystem II revealed by X-ray crystallography. Proc. Natl. Acad. Sci. USA 106, 8567-8572 (2009)

34. Y. Umena, K. Kawakami, J.R. Shen, N. Kamiya, Crystal structure of oxygen-evolving photosystem II at a resolution of $1.9 \AA$. Nature $\mathbf{4 7 3}$ 55-60 (2011)

35. N. Cox, M. Retegan, F. Neese, D.A. Pantazis, A. Boussac, W. Lubit, Electronic structure of the oxygen-evolving complex in photosystem II prior to O-O bond formation. Science 345, 804-808 (2004)

36. M. Suga, F. Akita, K. Hirata, G. Ueno, H. Murakami, Y. Nakajima, T. Shimizu, K. Yamashita, M. Yamamoto, H. Ago, J.R. Shen, Native structure of photosystem II at $1.95 \AA$ A resolution viewed by femtosecond X-ray pulses. Nature 517, 99-103 (2015)

37. B. Kok, B. Forbush, M. McGloin, Cooperation of charges in photosynthetic $\mathrm{O}_{2}$ evolution. I. A linear four step mechanism. Photochem. Photobiol. 11, 457-475 (1970)

38. D.J. Vinyard, G.M. Ananyev, G.C. Dismukes, Photosystem II: the reaction center of oxygenic photosynthesis. Annu. Rev. Biochem. 82, 577-606 (2013)

39. J. Yano, J. Kern, K.D. Irrgang, M.J. Latimer, U. Bergmann, X-ray damage to the $\mathrm{Mn}_{4} \mathrm{Ca}$ complex in single crystals of photosystem II: a case study for metalloprotein crystallography. Proc. Natl. Acad. Sci. 102, 12047-12052 (2005)

40. K.A. Åhrling, S. Peterson, S. Styring, An oscillating manganese electron paramagnetic resonance signal from the $\mathrm{S} 0$ state of the oxygen evolving complex in photosystem II. Biochemistry 36, 13148-13152 (1997)

41. J. Messinge, J.H.A. Nugent, M.C.W. Evans, Detection of an EPR multiline signal for the S0 state in photosystem II. Biochemistry 36, 11055-11060 (1997)

42. J. Messinger, J.H. Robblee, W.O. Yu, K. Sauer, V.K. Yachandra, M.P. Klein The SO state of the oxygen evolving complex in photosystem II is paramagnetic detection of an EPR multiline signal. J. Am. Chem. Soc. 119, 11349-11350 (1997)

43. D. Koulougliotis, D.J. Hirsh, G.W. Brudvig, The oxygen-evolving center of photosystem II is diamagnetic in the S1 resting state. J. Am. Chem. Soc. 114, 8322-8323 (1992)

44. E. Schlodder, H.T. Witt, Stoichiometry of proton release from the cataIytic center in photosynthetic water oxidation: reexamination by a glass electrode study at pH 5.5-7.2. J. Biol. Chem. 274, 30387-30392 (1999)

45. D.A. Pantazis, W. Ames, N. Cox, W. Lubitz, F. Neese, Two interconvertible structures that explain the spectroscopic properties of the oxygenevolving complex of photosystem II in the S2 state. Angew. Chem. Int. Ed. 51, 9935-9940 (2012)

46. J.L. Zimmermann, A.W. Rutherford, Electron paramagnetic resonance properties of the S2 state of the oxygen-evolving complex of photosystem II. Biochemistry 25, 4609-4615 (1986)

47. A.V. Astashkin, Y. Kodera, A. Kawamori, Pulsed EPR study of manganese $\mathrm{g}=4.1$ signal in plant photosystem II. J. Magn. Reson. Ser. B 105, 113-119 (1994)

48. A. Haddy, K.V. Lakshmi, G.W. Brudvig, H.A. Frank, Q-band EPR of the S2 state of photosystem II confirms an $S=5 / 2$ origin of the X-band $g=4.1$ signal. Biophys. J. 87, 2885-2896 (2004)
49. A. Haddy, EPR spectroscopy of the manganese cluster of photosystem II. Photosynth. Res. 92, 357-368 (2004)

50. R. Pokhrel, G.W. Brudvig, Oxygen-evolving complex of photosystem II: correlating structure with spectroscopy. Phys. Chem. Chem. Phys. 16, 11812-11821 (2014)

51. D.J. Vinyard, S. Khan, M. Askerka, V.S. Batista, G.W. Brudvig, Energetics of the $\mathrm{S} 2$ state spin isomers of the oxygen-evolving complex of photosystem II. J. Phys. Chem. B 121, 1020-1025 (2017)

52. D. Bovi, D. Narzi, L. Guidoni, The $\mathrm{S} 2$ state of the oxygen-evolving complex of photosystem II explored by QM/MM dynamics: spin surfaces and metastable states suggest a reaction path towards the $\mathrm{S} 3$ state. Angew. Chem. Int. Ed. 52, 11744-11749 (2013)

53. M. Shoji, H. Isobe, K. Yamaguchi, QM/MM study of the S2 to S3 transition reaction in the oxygenevolving complex of photosystem II. Chem. Phys. Lett. 636, 172-179 (2015)

54. M. Pérez Navarro, W.M. Ames, H. Nilsson, T. Lohmiller, D.A. Pantazis, L. Rapatskiy, M. Nowaczyk, F. Neese, A. Boussac, J. Messinger, W. Lubitz, N. Cox, Ammonia binding to the oxygen-evolving complex of photosystem ii identifies the solvent exchangeable oxygen bridge ( $\mu$-oxo) of the manganese tetramer. Proc. Natl. Acad. Sci. USA 110, 15561-15566 (2013)

55. P.H. Oyala, T.A. Stich, R.J. Debus, R.D. Britt, Ammonia binds to the dangler manganese of the photosystem II oxygen evolving complex. J. Am. Chem. Soc. 137, 8829-8837 (2015)

56. M. Askerka, D.J. Vinyard, G.W. Brudvig, V.S. Batista, $\mathrm{NH}_{3}$ binding to the $\mathrm{S} 2$ state of the $\mathrm{O}_{2}$-evolving complex of photosystem II: analogue to $\mathrm{H}_{2} \mathrm{O}$ binding during the $\mathrm{S} 2 \rightarrow \mathrm{S} 3$ transition. Biochemistry 54, 5783-5786 (2015)

57. D.J. Vinyard, M. Askerka, R.J. Debus, V.S. Batista, G.W. Brudvig, Ammonia binding in the second coordination sphere of the oxygen-evolving complex of photosystem II. Biochemistry 55, 4432 (2016)

58. M. Askerka, G.W. Brudvig, V.S. Batista, The $\mathrm{O}_{2}$-evolving complex of photosystem II: recent insights from quantum mechanics/molecular mechanics (QM/MM), extended X-ray absorption fine structure (EXAFS), and femtosecond X-ray crystallography data. Acc. Chem. Res. 50, 41-48 (2017)

59. M. Capone, D. Narzi, D. Bovi, L. Guidoni, Mechanism of water delivery to the active site of photosystem II along the S2 to S3 transition. J. Phys. Chem. Lett. 7, 592-596 (2016)

60. P.E.M. Siegbahn, Water oxidation mechanism in photosystem II, including oxidations, proton release pathways, $\mathrm{O}-\mathrm{O}$ bond formation and $\mathrm{O}_{2}$ release. Biochim. Biophys. Acta 1827, 1003-1019 (2013)

61. P.E.M. Siegbahn, O-O bond formation in the $\mathrm{S} 4$ state of the oxygenevolving complex in photosystem II. Chem. Eur. J. 12, 9217-9227 (2006)

62. P.E.M. Siegbahn, Recent theoretical studies of water oxidation in photosystem II. J. Photochem. Photobiol. B 104, 94-99 (2011)

63. D.C. Ashley, $\mathrm{M} . \mathrm{H}$. Baik, The electronic structure of $[\mathrm{Mn}(\mathrm{V})=\mathrm{O}]$ : what is the connection between oxyl radical character, physical oxidation state, and reactivity? ACS Catal. 6, 7202-7216 (2016)

64. J. Barber, A mechanism for water splitting and oxygen production in photosynthesis. Nat. Plants 3, 17041 (2017)

65. E.M. Sproviero, J.A. Gascon, J.P. McEvoy, G.W. Brudvig, V.S. Batista, Quantum mechanics/molecular mechanics study of the catalytic cycle of water splitting in photosystem II. J. Am. Chem. Soc. 130, 3428-3442 (2008)

66. Y. Gao, T. Åkermark, J.H. Liu, L.C. Sun, B. Åkermark, Nucleophilic attack of hydroxide on a MnV Oxo complex: a model of the O-O bond formation in the oxygen evolving complex of photosystem II. J. Am. Chem. Soc. $131,8726-8727$ (2009)

67. T. Taguchi, Preparation and properties of a monomeric high-spin $\mathrm{Mn}^{\vee}$ oxo complex. J. Am. Chem. Soc. 134, 1996-1999 (2012)

68. B.M. Sjöberg, A never-ending story. Science 329, 1475-1476 (2010)

69. V.V. Barynin, M.M. Whittaker, S.V. Antonyuk, V.S. Lamzin, P.M. Harrison, P.J. Artymiuk, J.W. Whittaker, Crystal structure of manganese catalase from Lactobacillus plantarum. Structure 9, 725-738 (2001)

70. A.B. Tomter, G. Zoppellaroa, N.H. Andersena, H.-P. Hersletha, M. Hammerstada, Å.K. Røhr, G.K. Sandvika, K.R. Stranda, G.E. Nilssona, C.B. Bell III, A.-L. Barrac, E. Blasco, L.L. Pape, E.I. Solomon, K.K. Andersson, Ribonucleotide reductase class I with different radical generating clusters. Coord. Chem. Rev. 257, 3-26 (2013) 
71. J.M. Younker, C.M. Krest, W. Jiang, C. Krebs, J.M. Bollinger, M.T. Green, Structural analysis of the Mn(IV)/Fe(III) cofactor of chlamydia trachomatis ribonucleotide reductase by extended $x$-ray absorption fine structure spectroscopy and density functional theory calculation. J. Am. Chem. Soc. 130, 15022-15027 (2008)

72. N. Voevodskaya, F. Lendzian, O. Sanganas, A. Grundmeier, A. Graslund, M. Haumann, Redox intermediates of the Mn-Fe site in Subunit R2 of Chlamydia trachomatis ribonucleotide reductase a X-ray absorption and EPR study. J. Biol. Chem. 284, 4555-4566 (2009)

73. J.A. Cotruvo, J. Stubbe, Class I ribonucleotide reductases: metallocofactor assembly and repair in vitro and in vivo. Annu. Rev. Biochem. 80 733-767 (2011)

74. C. Roshick, E.R. Iliffe-Lee, G. McClarty, Cloning and characterization of ribonucleotide reductase from Chlamydia trachomatis. J. Biol. Chem. 275, 38111-38119(2000)

75. A. Graslund, P. Nordlund, The radical site in chlamydial ribonucleotide reductase defines a new R2 subclass. Science 305, 245-248 (2004)

76. W. Jiang, L. Saleh, E.W. Barr, J. Xie, M.M. Gardner, C. Krebs, J.M. Bollinger, Branched activation- and catalysis specific pathways for electron relay to the manganese/iron cofactor in ribonucleotide reductase from Chlamydia trachomatis. Biochemistry 47, 8477-8484 (2008)

77. W. Jiang, J. Xie, H. Nørgaard, J.M. Bollinger, C. Krebs, Rapid and quantitative activation of Chlamydia trachomatis ribonucleotide reductase by hydrogen peroxide. Biochemistry 47, 4477-4483 (2008)

78. J.M. Bollinger, W. Jiang, M.T. Green, C. Krebs, The manganese(IV)/iron(III) cofactor of Chlamydia trachomatis ribonucleotide reductase: structure, assembly, radical initiation, and evolution. Curr. Opin. Struct. Biol. 18 650-657 (2008)

79. W. Jiang, D. Yun, L. Saleh, J.M. Bollinger, C. Krebs, Formation and function of the manganese(IV)/iron(III) cofactor in Chlamydia trachomatis ribonucleotide reductase. Biochemistry 47, 13736-13744 (2008)

80. C.S. Andersson, M. Öhrström, A. Popovic-Bijelic, A. Grá slund, P. Stenmark, M. Högbom,'The manganese ion of the heterodinuclear Mn/ Fe cofactor in Chlamydia trachomatis ribonucleotide reductase R2c is located at metal position. J. Am. Chem. Soc. 134, 123-125 (2012)

81. L.M.K. Dassama, A.K. Boal, C. Krebs, A.C. Rosenzweig, J.M. Bollinger, Evidence that the beta subunit of Chlamydia trachomatis ribonucleotide reductase is active with the manganese ion of its manganese(IV)/ iron(III) cofactor in site. J. Am. Chem. Soc. 134, 2520-2523 (2012)

82. L.M.K. Dassama, C. Krebs, J.M. Bollinger, A.C. Rosenzweig, A.K. Boal, Structural basis for assembly of the $\mathrm{Mn}(\mathrm{IV}) / \mathrm{Fe}$ (III) cofactor in the class Ic ribonucleotide reductase from Chlamydia trachomatis. Biochemistry $\mathbf{5 2}$ 6424-6436 (2013)

83. Y. Kwak, W. Jiang, L.M.K. Dassama, K. Park, C.B. Bell, L.V. Liu, S.D. Wong, M. Saito, Y. Kobayashi, S. Kitao, M. Seto, Y. Yoda, E. Ercan Alp, J. Zhao, J.M. Bollinger, C. Krebs, E.I. Solomon, Geometric and electronic structure of the $\mathrm{Mn}(\mathrm{IV}) \mathrm{Fe}(\mathrm{III})$ cofactor in class Ic ribonucleotide reductase: correlation to the class ia binuclear non-heme iron enzyme. J. Am. Chem. Soc. 135, 17573-17584 (2013)

84. H.S. Shafaat, J.J. Griese, D.A. Pantazis, K. Roos, C.S. Andersson, A. PovicBijelic, A. Graslund, P.E.M. Siegbahn, F. Neese, W. Lubitz, M. Högbom, N. Cox,'Electronic structural flexibility of heterobimetallic Mn/Fe cofactors: R2lox and R2c proteins. J. Am. Chem. Soc. 136, 13399-13409 (2014)

85. J. Livada, R.J. Martinie, L.M.K. Dassama, C. Krebs, J.M. Bollinger, A. Silakov, Direct measurement of the radical translocation distance in the class I ribonucleotide reductase from Chlamydia trachomatis. J. Phys. Chem. B 119, 13777-13784 (2015)

86. R.J. Martinie, E.J. Blaesi, C. Krebs, J.M. Bollinger, A. Silakov, C.J. Pollock, Evidence for a di- $\mu$-oxo diamond core in the Mn(IV)/Fe(IV) activation intermediate of ribonucleotide reductase from Chlamydia trachomatis. J. Am. Chem. Soc. 139, 1950-1957 (2017)

87. K.R. Rose, M.K. Ghosh, A.O. Maggiolo, C.J. Pollock, E.J. Blaesi, V. Hajj, Y. Wei, L.J. Rajakovich, W. Chang, Y. Han, M. Hajj, C. Krebs, A. Silakov, M.E. Pandelia, J.M. Bollinger, A.K. Boal, Structural basis for superoxide activation of Flavobacterium johnsoniae class I ribonucleotide reductase and for radical initiation by its dimanganese cofactor. Biochemistry. (2018). https://doi.org/10.1021/acs.biochem.8b00247

88. M.M. Najafpour, T. Ehrenberg, M. Wiechen, P. Kurz, Calcium manganese(III) oxides $\left(\mathrm{CaMn}_{2} \mathrm{O}_{4} \cdot \mathrm{xH}_{2} \mathrm{O}\right)$ as biomimetic oxygen-evolving catalysts. Angew. Chem. Int. Ed. 49, 2233-2237 (2010)
89. Y. Gorlin, T.F. Jaramillo, A bifunctional nonprecious metal catalyst for oxygen reduction and water oxidation. J. Am. Chem. Soc. 132, 13612-13614 (2010)

90. Y. Gorlin, B.L. Kaiser, J.D. Benck, S. Gul, S.M. Webb, V.K. Yachandra, J. Yano, T.F. Jaramillo, In situ X-ray absorption spectroscopy investigation of a bifunctional manganese oxide catalyst with high activity for electrochemical water oxidation and oxygen reduction. J. Am. Chem. Soc. 135, 8525-8534 (2013)

91. Y. Gorlin, C.J. Chung, J.D. Benck, D. Nordlund, L. Seitz, T.C. Weng, D. Sokaras, B.M. Clemens, T.F. Jaramillo, Understanding interactions between manganese oxide and gold that lead to enhanced activity for electrocatalytic water oxidation. J. Am. Chem. Soc. 136, 4920-4926 (2014)

92. C.H. Kuo, W. Li, L. Pahalagedara, A.M.E. Sawy, D. Kriz, N. Genz, C. Guild, T. Ressler, S.L. Suib, J. He, Understanding the role of gold nanoparticles in enhancing the catalytic activity of manganese oxides in water oxidation reactions. Angew. Chem. Int. Ed. 54, 2345-2350 (2015)

93. I. Zaharieva, P. Chernev, M. Risch, K. Klingan, M. Kohlhoff, A. Fischer, H. Dau, Electrosynthesis functional, and structural characterization of a water-oxidizing manganese oxide. Energy Environ. Sci. 5, 7081-7089 (2012)

94. N. Birkner, S. Nayeri, B. Pashaei, M.M. Najafpour, W.H. Casey, A. Navrotsky, Energetic basis of catalytic activity of layered nanophase calcium manganese oxides for water oxidation. Proc. Natl. Acad. Sci. USA. 110, 8801-8806 (2013)

95. M. Huynh, C. Shi, S.J. Billinge, D.G. Nocera, Nature of activated manganese oxide for oxygen evolution. J. Am. Chem. Soc. 137, 14887-14904 (2015)

96. A. Indra, P.W. Menezes, I. Zaharieva, E. Baktash, J.P. Frommer, M. Schwarze, H. Dau, M. Driess, Active mixed-valent MnOx water oxidation catalysts through partial oxidation (corrosion) of nanostructured $\mathrm{MnO}$ particles. Angew. Chem. Int. Ed. 52, 13206-13210 (2013)

97. P.W. Menezes, A. Indra, P. Littlewood, M. Schwarze, C. Göbel, R. Schomäcker, M. Driess, Nanostructured manganese oxides as highly active water oxidation catalysts: a boost from manganese precursor chemistry. Chem. Sus. Chem. 7, 2202-2211 (2014)

98. C. Walter, P.W. Menezes, S. Orthmann, J. Schuch, P. Connor, B. Kaiser, M. Lerch, M. Driess, A molecular approach to manganese nitride acting as a high performance electrocatalyst in the oxygen evolution reaction. Angew. Chem. Int. Ed. 57, 698-702 (2018)

99. Y. Kim, J.H. Lee, H. Ha, S.W. Im, K.T. Nam, Material science lesson from the biological photosystem. Nano Convergence 3, 19 (2016)

100. J. Park, H. Kim, K. Jin, B.J. Lee, Y.S. Park, H. Kim, I. Park, K.D. Yang, H.Y. Jeong, J. Kim, K.T. Hong, H.W. Jang, K. Kang, K.T. Nam, A New water oxidation catalyst: lithium manganese pyrophosphate with tunable $\mathrm{Mn}$ valency. J. Am. Chem. Soc. 136, 4201-4211 (2014)

101. K. Jin, J. Park, J. Lee, K.D. Yang, G.K. Pradhan, U. Sim, D. Jeong, H. Jang, S. Park, D. Kim, N. Sung, S.H. Kim, S. Han, K.T. Nam, Hydrated manganese (II) phosphate $\left(\mathrm{Mn}_{3}\left(\mathrm{PO}_{4}\right)_{2} \cdot 3 \mathrm{H}_{2} \mathrm{O}\right)$ as a water oxidation catalyst. J. Am. Chem. Soc. 136, 7435-7443 (2014)

102. K. Jin, A. Chu, J. Park, D. Jeong, S.E. Jerng, U. Sim, H.-Y. Jeong, C.W. Lee, Y.S. Park, K.D. Yang, G.K. Pradhan, D. Kim, N. Sung, S.H. Kim, K.T. Nam, Partially oxidized sub-10 nm MnO nanocrystals with high activity for water oxidation catalysis. Sci. Rep. 5, 10279 (2015)

103. D. Jeong, K. Jin, S.E. Jerng, H. Seo, D. Kim, S.H. Nahm, S.H. Kim, K.T. Nam, $\mathrm{Mn}_{5} \mathrm{O}_{8}$ nanoparticles as efficient water oxidation catalysts at neutral $\mathrm{pH}$ ACS Catal. 5, 4624-4628 (2015)

104. K. Jin, H. Seo, H. Ha, Y. Kim, K.H. Cho, J.S. Hong, K.T. Nam, Recent advances in heterogeneous $\mathrm{Mn}$-based electrocatalysts toward biological photosynthetic $\mathrm{Mn}_{4} \mathrm{Ca}$ cluster. Catal. Today (2016). https://doi. org/10.1016/j.cattod.2016.12.041

105. K. Jin, H. Seo, T. Hayashi, M. Balamurugan, D. Jeong, Y.K. Go, J.S. Hong, K.H. Cho, H. Kakizaki, N. Bonnet-Mercier, M.G. Kim, S.H. Kim, R. Nakamura, K.T. Nam, Mechanistic investigation of water oxidation catalyzed by uniform, assembled $\mathrm{MnO}$ nanoparticles. J. Am. Chem. Soc. 139, 2277-2285 (2016)

106. H. Seo, S. Park, J.S. Hong, K.H. Cho, H. Ha, K. Jin, K.T. Nam, Water oxidation mechanism for $3 \mathrm{~d}$ transition metal oxide catalysts under neutral condition. J. Korean Ceram. Soc. 54, 1-8 (2017) 
107. J.T. Groves, M.K. Stern, Synthesis, characterization, and reactivity of oxomanganese(IV) porphyrin complexes. J. Am. Chem. Soc. 110, 8628-8638 (1988)

108. R.S. Czernuszewicz, Y.O. Su, M.K. Stern, K.A. Macor, D. Kim, J.T. Groves, T.G. Spiro, Oxomanganese(IV) porphyrins identified by resonance Raman and infrared spectroscopy. Weak bonds and the stability of the halffilled $t_{2 g}$ subshell. J. Am. Chem. Soc. 110, 4158-4165 (1988)

109. R.D. Arasasingham, G.X. He, T.C. Bruice, Mechanism of manganese porphyrin-catalyzed oxidation of alkenes. Role of manganese(IV)-oxo species. J. Am. Chem. Soc. 115, 7985-7991 (1993)

110. K.P. Bryliakov, D.E. Babushkin, E.P. Talsi, 1H NMR and EPR spectroscopic monitoring of the reactive intermediates of (Salen) Mn ${ }^{\text {III }}$ catalyzed olefin epoxidation. J. Mol. Cat. A Chem. 158, 19-35 (2000)

111. K.P. Bryliakov, O.A. Kholdeeva, M.P. Vanina, E.P. Talsi, Role of $\mathrm{Mn}^{\mathrm{IV}}$ species in $\mathrm{Mn}$ (salen) catalyzed enantioselective aerobic epoxidations of alkenes: an EPR study. J. Mol. Cat A Chem. 178, 47-53 (2002)

112. G. Yin, M. Buchalova, A.M. Danby, C.M. Perkins, D. Kitko, J.D. Carter, W.M. Scheper, D.H. Busch, Olefin oxygenation by the hydroperoxide adduct of a nonheme manganese(IV) complex: epoxidations by a metallo-peracid produces gentle selective oxidations. J. Am. Chem Soc. 127, 17170-17171 (2005)

113. G. Yin, A.M. Danby, D. Kitko, J.D. Carter, W.M. Scheper, D.H. Busch, Olefin epoxidation by alkyl hydroperoxide with a novel cross-bridged cyclam manganese complex: demonstration of oxygenation by two distinct reactive intermediates. Inorg. Chem. 46, 2173-2180 (2007)

114. G. Yin, A.M. Danby, D. Kitko, J.D. Carter, W.M. Scheper, D.H. Busch, Understanding the selectivity of a moderate oxidation catalyst: hydrogen abstraction by a fully characterized, activated catalyst, the robust dihydroxo manganese(IV) complex of a bridged cyclam. J. Am. Chem. Soc. 129, 1512-1513 (2007)

115. G. Yin, A.M. Danby, D. Kitko, J.D. Carter, W.M. Scheper, D.H. Busch, Oxidative reactivity difference among the metal oxo and metal hydroxo moieties: $\mathrm{pH}$ dependent hydrogen abstraction by a manganese(IV) complex having two hydroxide ligands. J. Am. Chem. Soc. 130, 16245-16253 (2008)

116. S.H. Kim, H. Park, M.S. Seo, M. Kubo, T. Ogura, J. Klajn, D.T. Gryko, J.S. Valentine, W. Nam, Reversible O-O bond cleavage and formation between $\mathrm{Mn}(\mathrm{IV})$-peroxo and $\mathrm{Mn}(\mathrm{V})$-oxo corroles. J. Am. Chem. Soc. 132, 14030-14032 (2010)

117. S.C. Sawant, X. Wu, J. Cho, K.-B. Cho, S.H. Kim, M.S. Seo, Y.-M. Lee, M. Kubo, T. Ogura, S. Shaik, W. Nam, Water as an oxygen source: synthesis, characterization, and reactivity studies of a mononuclear nonheme manganese(IV) oxo complex. Angew. Chem. Int. Ed. 49, 8190-8194 (2010)

118. I. Garcia-Bosch, A. Company, C.W. Cady, S. Styring, W.R. Browne, X. Ribas, M. Costas, Evidence for a precursor complex in $\mathrm{C}-\mathrm{H}$ hydrogen atom transfer reactions mediated by a manganese(IV) oxo complex. Angew. Chem. Int. Ed. 50, 5648-5653 (2011)

119. I. Garcia-Bosch, A. Company, X. Fontrodona, X. Ribas, M. Costas, Efficient and selective peracetic acid epoxidation catalyzed by a robust manganese catalyst. Org. Lett. 10, 2095-2098 (2008)

120. X. Wu, M.S. Seo, K.M. Davis, Y.-M. Lee, J. Chen, K.-B. Cho, Y.N. Pushkar, W. Nam, A highly reactive mononuclear non-heme manganese(IV)Oxo complex that can activate the strong $\mathrm{C}-\mathrm{H}$ bonds of alkanes. J. Am. Chem. Soc. 133, 20088-20091 (2011)

121. S. Kim, K.-B. Cho, Y.-M. Lee, J. Chen, S. Fukuzumi, W. Nam, Factors controlling the chemoselectivity in the oxidation of olefins by nonheme manganese(IV)-oxo complexes. J. Am. Chem. Soc. 138, 10654-10663 (2016)

122. N. Sharma, J. Jung, Y.-M. Lee, M.S. Seo, W. Nam, S. Fukuzumi, Multi-electron oxidation of anthracene derivatives by nonheme manganese(IV)-oxo complexes. Chem. Eur. J. 23, 7125-7131 (2017)

123. H. Yoon, Y. Morimoto, Y.-M. Lee, W. Nam, S. Fukuzumi, Electron-transfer properties of a nonheme manganese(iv)-oxo complex acting as a stronger one-electron oxidant than the iron(iv)-oxo analogue. Chem. Commun. 48, 11187 (2012)

124. J. Chen, Y.-M. Lee, K.M. Davis, X. Wu, M.S. Seo, K.-B. Cho, H. Yoon, Y.J. Park, S. Fukuzumi, Y.N. Pushkar, W. Nam, A mononuclear non-heme manganese(IV)-oxo complex binding redox-inactive metal ions. J. Am. Chem. Soc. 135, 6388-6391 (2013)
125. H. Yoon, Y.-M. Lee, X. Wu, K.-B. Cho, R. Sarangi, W. Nam, S. Fukuzumi, Enhanced electron-transfer reactivity of nonheme manganese(IV)oxo complexes by binding scandium ions. J. Am. Chem. Soc. 135, 9186-9194 (2013)

126. R.V. Ottenbacher, K.P. Bryliakov, E.P. Talsi, Nonheme manganese-catalyzed asymmetric oxidation. A Lewis acid activation versus oxygen rebound mechanism: evidence for the "Third Oxidant". Inorg. Chem. 49, 8620-8628 (2010)

127. J.W. de Boer, W.R. Browne, J. Brinksma, P.L. Alsters, R. Hage, B.L. Feringa, Mechanism of Cis-dihydroxylation and epoxidation of alkenes by highly $\mathrm{H}_{2} \mathrm{O}_{2}$ efficient dinuclear manganese catalysts. Inorg. Chem. 46, 6353-6372 (2007)

128. J.W. de Boer, W.R. Browne, S.R. Harutyunyan, L. Bini, T.D. TiemersmaWegman, P.L. Alsters, R. Hage, B.L. Feringa, Manganese catalysed asymmetric cis-dihydroxylation with $\mathrm{H}_{2} \mathrm{O}_{2}$. Chem. Commun. 32 3747-3749 (2008)

129. Z. Lv, C. Choe, Y. Wu, H. Wang, Z. Chen, G. Li, G. Yin, Non-redox metal ions accelerated oxygen atom transfer by $\mathrm{Mn}-\mathrm{Me}_{3} \mathrm{tacn}$ complex with $\mathrm{H}_{2} \mathrm{O}_{2}$ as oxygen resource. Mol. Catal. 448, 46-52 (2018)

130. S.H. Lee, L. Xu, B.K. Park, Y.V. Mironov, S.H. Kim, Y.J. Song, C. Kim, Y. Kim, S.-J. Kim, Efficient olefin epoxidation by robust Re 4 cluster-supported Mn'II complexes with per acids: evidence of simultaneous operation of multiple active oxidant species, $\mathrm{Mn}^{\mathrm{V}}=\mathrm{O}, \mathrm{Mn}^{\mathrm{IV}}=\mathrm{O}$, and $\mathrm{Mn}^{\mathrm{III}}-\mathrm{OOC}(\mathrm{O}) \mathrm{R}$. Chem. Eur. J. 16, 4678-4685 (2010)

131. C. Choe, L. Yang, Z. Lv, W. Mo, Z. Chen, G. Li, G. Yin, Redox-inactive metal ions promoted the catalytic reactivity of non-heme manganese complexes towards oxygen atom transfer. Dalton Trans. 44, 9182-9192 (2015)

132. K.W. Kwong, T.-H. Chen, W. Luo, H. Jeddi, R. Zhang, A biomimetic oxidation catalyzed by manganese(III) porphyrins and iodobenzene diacetate: synthetic and mechanistic investigations. Inorg. Chim. Acta 430, 176-183 (2015)

133. W. Dai, S. Shang, Y. Lv, G. Li, C. Li, S. Gao, Highly chemoselective and enantioselective catalytic oxidation of heteroaromatic sulfides via highvalent manganese(IV)-oxo cation radical oxidizing intermediates. ACS Catal. 7, 4890-4895 (2017)

134. G.B. Shul'pin, D.S. Nesterov, L.S. Shul'pina, A.J.L. Pombeiro, A hydroperoxo-rebound mechanism of alkane oxidation with hydrogen peroxide catalyzed by binuclear manganese(IV) complex in the presence of an acid with involvement of atmospheric dioxygen. Inorg. Chim. Acta. 455 666-676 (2017)

135. D. Mondal, M.C. Majee, Synthesis and structural characterization of a new high-valentbis(oxo)-bridged manganese(IV) complex and its catechol oxidase activity. Inorg. Chim. Acta 465, 70-77 (2017)

136. K. Srinivasan, P. Michaud, J.K. Kochi, Epoxidation of olefins with cationic (salen)manganese(III) complexes. The modulation of catalytic activity by substituents. J. Am. Chem. Soc. 108, 2309-2320 (1986)

137. T.J. Collins, S.W. Gordon-Wylie, A manganese(V)-oxo complex. J. Am. Chem. Soc. 111, 4511-4513 (1989)

138. T.J. Collins, R.D. Powell, C. Slebodnick, E.S. Uffelman, A water-stable manganese(V)-oxo complex: definitive assignment of a nu.Mnv. tplbond.O infrared vibration. J. Am. Chem. Soc. 112, 899-901 (1990)

139. W. Zhang, J.L. Loebach, S.R. Wilson, E.N. Jacobsen, Enantioselective epoxidation of unfunctionalized olefins catalyzed by salen manganese complexes. J. Am. Chem. Soc. 112, 2801-2803 (1990)

140. J.M. Workman, R.D. Powell, A.D. Procyk, T.J. Collins, D.F. Bocian, Vibrational and electrochemical properties of a series of stable manganese(V)-oxo complexes. Inorg. Chem. 31, 1548-1550 (1992)

141. F.M. MacDonnell, N.L.P. Fackler, C. Stern, T.V. O'Halloran, Air oxidation of a five-coordinate $\mathrm{Mn}$ (III) dimer to a high-valent oxomanganese(V) complex. J. Am. Chem. Soc. 116, 7431-7432 (1994)

142. J.T. Groves, J. Lee, S.S. Marla, Detection and characterization of an oxomanganese(V) porphyrin complex by rapid-mixing stopped-flow spectrophotometry. J. Am. Chem. Soc. 119, 6269-6273 (1997)

143. D. Feichtinger, D.A. Plattner, Direct proof for $\mathrm{O}=\mathrm{Mn}^{\vee}$ (salen) complexes Angew. Chem. Int. Ed. 36, 1718-1719 (1997)

144. C.G. Miller, S.W. Gordon-Wylie, C.P. Horwitz, S.A. Strazisar, D.K. Peraino, G.R. Clark, S.T. Weintraub, T.J. Collins, A method for driving O-atom transfer: secondary ion binding to a tetraamide macrocyclic ligand. J. Am. Chem. Soc. 120, 11540-11541 (1998) 
145. N. Jin, J.T. Groves, Unusual kinetic stability of a ground-state singlet oxomanganese $(V)$ porphyrin. Evidence for a spin state crossing effect. J. Am. Chem. Soc. 121, 2923-2924 (1999)

146. N. Jin, J.L. Bourassa, S.C. Tizio, J.T. Groves, Reversible oxygen atom transfer between an oxomanganese(v) porphyrin and bromide: a haloperoxidase mimic with enzymatic rates. Angew. Chem. Int. Ed. 39 3849-3851 (2000)

147. W. Nam, I. Kim, M.H. Lim, H.J. Choi, J.S. Lee, H.G. Jang, Isolation of an oxomanganese $(\mathrm{V})$ porphyrin intermediate in the reaction of a manganese(III) porphyrin complex and $\mathrm{H}_{2} \mathrm{O}_{2}$ in aqueous solution. Chem. Eur. J. 8, 2067-2071 (2002)

148. B.C. Gilbert, J.R.L. Smith, A.M.I. Payeras, J. Oakes, Formation and reaction of $\mathrm{O}=\mathrm{Mn}^{\mathrm{V}}$ species in the oxidation of phenolic substrates with $\mathrm{H}_{2} \mathrm{O}_{2}$ catalysed by the dinuclearmanganese(IV) 1,4,7-trimethyl-1,4,7-triazacyclononane complex $\left[\mathrm{Mn}_{2}^{\mathrm{IV}}(\mu-\mathrm{O}) 3(\mathrm{TMTACN}) 2\right](\mathrm{PF} 6) 2$. Org. Biomol. Chem. 2, 1176-1180 (2004)

149. J.P. Collman, L. Zeng, J.I. Brauman, Donor ligand effect on the nature of the oxygenating species in $\mathrm{Mn}^{\mathrm{III}}$ (salen)-catalyzed epoxidation of olefins: experimental evidence for multiple active oxidants. Inorg. Chem. 43, 2672-2679 (2004)

150. S.H. Wang, B.S. Mandimutsira, R. Todd, B. Ramdhanie, J.P. Fox, D.P. Goldberg, Catalytic sulfoxidation and epoxidation with a $\mathrm{Mn}$ (III) triazacorrole: evidence for a "Third Oxidant" in high-valent porphyrinoid oxidations. J. Am. Chem. Soc. 126, 18-19 (2004)

151. W.J. Song, M.S. Seo, S. DeBeer George, T. Ohta, R. Song, M.-J. Kang, T. Tosha, T. Kitagawa, E.I. Solomon, W. Nam, Synthesis, characterization, and reactivities of manganese(V)-oxo porphyrin complexes. J. Am. Chem. Soc. 129, 1268-1277 (2007)

152. C. Arunkumar, Y.-M. Lee, J.Y. Lee, S. Fukuzumi, W. Nam, Hydrogen-atom abstraction reactions by manganese( $V$ )- and manganese(IV)-oxo porphyrin complexes in aqueous solution. Chem. Eur. J. 15, 11482-11489 (2009)

153. H.-Y. Liu, F. Yam, Y.-T. Xie, X.-Y. Li, C.K. Chang, A bulky bis-pocket manganese $(V)$-oxo corrole complex: observation of oxygen atom transfer between triply bonded $\mathrm{Mn}^{\mathrm{V}} \equiv \mathrm{O}$ and alkene. J. Am. Chem. Soc. 131, 12890-12891 (2009)

154. J.Y. Lee, Y.-M. Lee, H. Kotani, W. Nam, S. Fukuzumi, High-valent manganese $(V)$-oxo porphyrin complexes in hydride transfer reactions. Chem. Commun. 6, 704-706 (2009)
155. P. Leeladee, D.P. Goldberg, Epoxidations catalyzed by manganese(V) oxo and imido complexes: role of the oxidant-Mn-oxo(imido) intermediate. Inorg. Chem. 49, 3083-3085 (2010)

156. S. Fukuzumi, T. Mizuno, T. Ojiri, Catalytic electron-transfer oxygenation of substrates with water as an oxygen source using manganese porphyrins. Chem. Eur. J. 18, 15794-15804 (2012)

157. M. Guo, H. Dong, J. Li, B. Cheng, Y. Huang, Y. Feng, A. Lei, Spectroscopic observation of iodosylarenemetalloporphyrin adducts and manganese(V)-oxo porphyrin species in a cytochrome P450 analogue. Nat. Commun. (2012). https://doi.org/10.1038/ncomms2196

158. R.A. Baglia, M. Dürr, I. Ivanović-Burmazović, D.P. Goldberg, Activation of a high-valent manganese-oxo complex by a nonmetallic Lewis acid. Inorg. Chem. 53, 5893-5895 (2014)

159. H.M. Neu, T. Yang, R.A. Baglia, T.H. Yosca, M.T. Green, M.G. Quesne, S.P. de Visser, D.P. Goldberg, Oxygen-atom transfer reactivity of axially ligated $\mathrm{Mn}(\mathrm{V})$-oxo complexes: evidence for enhanced electrophilic and nucleophilic pathways. J. Am. Chem. Soc. 136, 13845-13852 (2014)

160. R.E. Schreiber, H. Cohen, G. Leitus, S.G. Wolf, A. Zhou, L. Que, R. Neumann, Reactivity and $\mathrm{O}_{2}$ formation by $\mathrm{Mn}(\mathrm{IV})$ - and $\mathrm{Mn}(\mathrm{V})$-hydroxo species stabilized within a polyfluoroxometalate framework. J. Am. Chem. Soc. $137,8738-8748$ (2015)

161. S. Hong, Y.-M. Lee, M. Sankaralingam, A.K. Vardhaman, Y.J. Park, K.-B. Cho, T. Ogura, R. Sarangi, S. Fukuzumi, W. Nam, A manganese(V)-oxo complex: synthesis by dioxygen activation and enhancement of its oxidizing power by binding scandium ion. J. Am. Chem. Soc. 138, 8523-8532 (2016)

162. K. Oohora, H. Meichin, Y. Kihira, H. Sugimoto, Y. Shiro, T. Hayashi, Manganese( $\mathrm{V}$ ) porphycene complex responsible for inert $\mathrm{C}-\mathrm{H}$ bond hydroxylation in a myoglobin matrix. J. Am. Chem. Soc. 139 18460-18463 (2017)

163. J.P.T. Zaragoza, M.A. Siegler, D.P. Goldberg, A reactive manganese(IV)hydroxide complex: a missing intermediate in hydrogen atom transfer by high-valent metal-oxo porphyrinoid compounds. J. Am. Chem. Soc. 140, 4380-4390 (2018)

\section{Submit your manuscript to a SpringerOpen ${ }^{\circ}$ journal and benefit from:}

- Convenient online submission

- Rigorous peer review

- Open access: articles freely available online

- High visibility within the field

- Retaining the copyright to your article

Submit your next manuscript at $\boldsymbol{\nabla}$ springeropen.com 